\title{
SUÇ UYDURMA SUÇU (TCK m. 271)
}

\author{
The Crime of Fabricating an Offence
}

\section{Burak TAŞ ${ }^{*}$}

\begin{abstract}
$\ddot{\mathbf{O z}}$
5237 sayıl1 Türk Ceza Kanunu'nun 271. maddesinde, “Kanunda, işlenmediği bilinen bir suçun, yetkili makamlara işlenmiş gibi ihbar edilmesi ya da işlenmeyen bir suçun delil veya emarelerinin soruşturma yapılmasını sağlayacak biçimde uyduran kimseye üç yıla kadar hapis cezası verilir." şeklinde düzenlenen suç uydurma suçu, bu çalışmanın konusunu oluşturmaktadır. Suç uydurma suçu hakkında öncelikle genel bilgiler verilmiş ve koruduğu hukuki değer araştırılmıştır. Ardından suçun maddi, manevi ve hukuka aykırılık unsurları incelenmiştir. Tipikliğin maddi unsurları bağlamında şekli uydurma ve maddi uydurma şeklindeki iki seçimlik hareket, ayrı ayrı incelenme konusu yapılmıştır. Şekli suç uydurma bağlamında ihbarın kapsamı belirlenmiş ve her türlü bildirimin ihbar niteliğinde sayılıp sayılamayacağ tartışılmıştır. Tipikliğin manevi unsuru bağlamında suçun olası kastla işlenip işlenemeyeceği araştırılmıştır. Hukuka aykırılık unsuru bağlamında ise hakkın kullanılması ve görevin ifası şeklinde iki hukuka uygunluk sebebinin bu suç bağlamında uygulanabilirliği araştırılmıştır. Devamında suçun özel görünüş biçimleri teşebbüs iştirak ve içtima bağlamında araştırılmış ve nihayetinde suçun muhakeme süreci ortaya konmuş ve sonuca varılmıştır.
\end{abstract}

Anahtar Kelimeler: Adliyeye Karşı Suçlar, Suç Uydurma, Suçun Unsurları, Yetkili Makamlar, İhbar,

\begin{abstract}
The crime of "fabricating an offence" which regulated as "Any person who denunciates a crime that is known to be not being committed to competent authorities or fabricating actual or circumstantial evidence in a manner to initiate investigations, is sentenced to imprisonment of up to three years" in article 271 of the Turkish Criminal Code no 5237 forms the subject of this study. First of all, general information was given about the crime of fabricating an offence, and the legal value it protected was investigated. Then, the material, inmaterial and illegal elements of the crime were examined. In the context of their material elements, two optional movements, formal fabricating and material fabricating, were examined separately. Within the context of formal fabrication, the scope of the denunciation was determined and it was discussed whether any notification could be regarded as denunciation. In the context of the inmaterial element, it has been investigated whether the crime can be committed by eventual intent or not. In the context of the illegality element, the applicability of the two reasons of compliance
\end{abstract}

Bu makale Etik Kurul İznine tabi değildir.

* Arş. Gör., Ankara Sosyal Bilimler Üniversitesi Ceza ve Ceza Muhakemesi Hukuku Anabilim Dal1, burak.tas@asbu.edu.tr, http://orcid.org/0000-0001-6481-1580 
IIIIIIIIII

with the law, the exercise of the right and the performance of the duty, in the context of this crime has been investigated. Subsequently, the special appearance forms of the crime were investigated in the context of undertaking, participation and socialization; and ultimately, the trial process of the crime was revealed and concluded.

Keywords: Crimes against Judiciary, Fabricating an Offence, Elements of Crime, Competent Authorities, Denunciation

\section{GÍRIŞ}

Suç uydurma suçu, 5237 sayılı Türk Ceza Kanunu'nun özel hükümleri düzenleyen ikinci kitabının "Millete ve Devlete Karş1 Suçlar”'1 içeren dördüncü kısmının "Adliyeye Karşı Suçlar" başl1klı ikinci bölümünde 271. maddede düzenlenmiştir. "Suç Uydurma” başlığı altında, işlenmediğini bildiği bir suçu, yetkili makamlara işlenmiş gibi ihbar eden ya da işlenmeyen bir suçun delil veya emarelerini soruşturma yapılmasını sağlayacak biçimde uyduran kimseye üç yıla kadar hapis cezası verileceği düzenlenmektedir.

Söz konusu suç, suç genel teorisi bağlamında finalist hareket teorisi esas alınarak tahlilci metotla incelenmiştir. Bu kapsamda tipiklik ve hukuka aykırılık unsuru üzerinden araştırma yapılmıştır. Tipikliğin maddi unsuru, tipikliğin manevi unsuru ve hukuka aykırılık unsuru bakımından suç izah edilmeye çalışılmıştır.

Öncelikle 765 sayılı TCK döneminde suç tasnii olarak düzenlenen bu suç ile 5237 sayılı TCK döneminde düzenlenen suç uydurma suçu unsurları bağlamında karşılaştırılmıştır. Farklılıkları ve benzerlikleri ortaya konduktan sonra bu suçun koruduğu hukuki değer, doktrindeki tartışmalara yer verilmek suretiyle incelenmiştir.

Tipikliğin maddi unsurlarında sırasıyla fail, mağdur, maddi konu ile fiil açıklanmıştır. Şekli ve maddi uydurma olarak doktrinde ikili bir ayrıma tutulan suç, seçimlik hareketleri bağlamında iki farklı başlık altında incelenmiştir. Kanunda bu suç için nitelikli haller öngörülmediği için sadece seçimlik iki hareket bağlamında inceleme yapılmıştır.

Tipikliğin manevi unsurları bakımından doğrudan kast, olası kast ve taksir araştırması yapılmıştır. Bu başlık altında doktrinde bu suçun olası kastla işlenip işlenemeyeceği ile ilgili görüşler incelenmiştir. Nihayetinde tipikliğin maddi unsurlarında hata (TCK m. 30/1) hükümlerinin uygulanırlığı araştırılmıştır.

Suçun hukuka aykırılık unsurunda, suç uydurma suçunun uygulamasında hukuka uygunluk sebebi olarak hakkın kullanılması ve görevin ifası araştırılmış ve uygulanabilme şartları belirtilmiştir.

Suçun özel görünüş biçimlerinde sırasıyla teşebbüs iştirak ve içtima kurumları incelenmiş ardından suçun muhakemesinin kapsamı ortaya konulmuştur. Nihayetinde olması gerekene yönelik değerlendirmelerde bulunulmuş ve sonuca varılmıştır. 


\section{SUÇ HAKKINDA GENEL BÍLGILER}

Suç uydurma suçu, 765 sayılı TCK m. 283'te "suç tasnii”" olarak şu şekilde düzenlenmekteydi: "(1)Vuku bulmadığını bildiği bir suçu Adliyeye veya keyfiyeti Adliyeye tevdie mecbur olan bir makama veya kanuni takib yapacak veya yaptırabilecek bir mercie vuku bulmuş gibi ihbar ile yahut vaki olmuyan bir suçun eserlerini takibata mübaşeret olunabilecek derecede uyduran kimse 30 aya kadar hapis cezasina mahkûm olur. (2)Adliye huzurunda sahte olarak bir suç işlediğini yahut bu suça iştirak eylediğini söyliyen kimse hakkında dahi aynı ceza tertib olunur."

5237 say1lı TCK m. 271'de bu suç tipi, 765 sayıl1 TCK dönemindeki unsurlarında değişiklik yapılmadan yine adliyeye karşı bir suç olarak düzenlenmiştir. ${ }^{2}$ Her iki TCK döneminde de bu suç seçimlik hareketli olarak düzenlenmiştir. ${ }^{3}$ Ancak 765 sayılı TCK' da suçun oluşumu açısından ihbar ${ }^{4}$ veya şikayetin yapılacağı makamlar üçlü bir ayrıma tabi tutulmuştur. ${ }^{5}$ Bu makamlar sirasiyla adliye, keyfiyeti adliyeye tevdie mecbur olan bir makam veya kanuni takib yapacak veya yaptırabilecek bir merci olarak düzenlenmiştir. 5237 sayılı TCK'da ise üçlü ayrımdan vazgeçilmiş ve sadece "yetkili makamlar" ifadesi tercih edilmiştir. ${ }^{6}$

\section{KORUNAN HUKUKİ DEĞER}

Suç uydurma suçu ile korunan hukuki değer, adli makamların boşa çalışmamasına yönelik zaman ve emek kaybının önüne geçilmesi, adliyenin hatalı karar vermesinin engellenmesi ve saygınlık ve itibarının korunmasıdır. ${ }^{7}$ $\mathrm{Bu}$ yolla adli mercilerin gereksiz yere gerçeği yansıtmayan ve asılsız

765 sayılı TCK m. 283/2'de yetkili makamlara, gerçeğe aykırı olarak, suçu işlediğini veya suça katıldığını bildiren kimsenin de suç uydurma suçuyla cezalandırılması öngörülmekteydi. Ancak 5237 sayılı TCK bu fiili suç tasnii fiilinden ayırmıș ve "suç üstlenme" suçu olarak ayrı bir maddede düzenlemiştir.

2 Ali Parlar ve Muzaffer Hatipoğlu, Türk Ceza Kanunu Yorumu 4. Cilt (3. Bask1, Seçkin Yayınları 2010) 4261.

3 V.Özer Özbek, Koray Doğan ve Pınar Bacaksız, Türk Ceza Hukuku Özel Hükümler (15. Bask1, Seçkin Yayıncılık 2020) 1160; Akif Yıldırım, İftira ve Suç Uydurma Suçları (1. Bask1, Adalet Yayınevi 2010) 3

4 "Ceza muhakemesi terimi olan ihbar, şikâyete bağlı olmayan suçlarda suçtan haberdar olan kimsenin bunu yetkili makamlara bildirmesidir.” Yıldırım (n 3) 116.

5 Ayhan Önder, Türk Ceza Hukuku Özel Hükümler (4. Bask1, Filiz Kitabevi 1994) 268.

6 Yildırım (n 3) 5.

7 Doğan Soyaslan, Ceza Özel Hukuku (12. Bask1, Yetkin Yayıncılık 2018) 741; Osman Yaşar, H. Tahsin Gökcan ve Mustafa Artuç, Yorumlu-Uygulamalı Türk Ceza Kanunu Cilt IV (1. Bask1, Adalet Yayınevi 2010) 7918; Parlar ve Hatipoğlu (n 2) 4261; Aynı şekilde madde gerekçesi ise şu şekildedir: "Madde, suç uydurma hâlini cezalandırmaktadır. Bu suretle adlî makamlarl gereksiz olarak işgal etmek veya yanlı̧̧ yollara yönlendirerek gereksiz yere uğraştırmak cezalandırılmış olmaktadır." 
IIIIIIIIII!

ihbarlarla yanlış yönlendirilerek meşgul edilmesi cezalandırılmaktadır.8 Suç uydurma fiilinin cezalandırılmasıyla mahkemelerin hatalı kararlar vermemesi ve yetkili makamların gerçekten işlenen suçların soruşturmasını daha etkili gerçekleştirebilmesi amaçlanmıştır."

Bu suçla aynı zamanda "kamusal adalet mekanizması kandırlmak suretiyle hem devlet hem de vatandaşlar" zarara uğramaktadır.10 Nitekim gerçekte işlenmemiş bir suçun soruşturulması ve kovuşturulması yoluyla vatandaşların adalet hizmetlerinin efektif bir şekilde yerine getirilmesi için ödemekle yükümlendiği vergiler amacına aykırı bir şekilde israf olacak ve vatandaşlar adli mercilere olan güvenlerini kaybedeceklerdir. ${ }^{11}$

Suç uydurma türünden fiiller, suç duyurusunda bulunmak (ihbar) hak ve görevinin kötüye kullanılması anlamına gelir. ${ }^{12}$ Adliyeye karş1 suçlar, fiilin türü bağlamında, belirli bir yükümlülüğün ihmali yahut hak veya yükümlülüğün aldatıcı davranışlara konu yapılmasıyla işlenebilmektedir. ${ }^{13}$ Suç işlendiğine yönelik ihbarda bulunulması, soruşturmayı yapılmasına sebebiyet veren ve nihayetinde de ceza kovuşturmasının yapılmasını gerektiren bir davranıştır. Uydurulan suç, gerçekte işlenmeyen bir fiil nedeniyle ceza davası açılması tehlikesini yarattığı için aldatıcı hareket oluşturur. Korunan hukuki değer bakımından, adli fonksiyonların gereksiz yere maddi gerçeği araştırması için mesai harcamasına yol açan hukuka aykırı fiil, aynı zamanda birey açısından da tehlike yaratmaktadır. ${ }^{14}$ Kanun koyucu. uydurma suç ihbarında bulunulmas1; gerçeğe uygun suç duyurusu "notitia criminis" yükümlügüne aykırllı oluşturduğu ve aldatıcı hareketle adli fonksiyonun ve yargı otoritesinin saptırılması sonucunu doğurduğu için kamusaltehlikeyaratmaktadır. ${ }^{15}$ Adliyenin işleyişini etkin bir şekilde devam ettirebilmesi bakımından gereksiz ihbar ve şikayetlerde bulunarak hakkın kötüye kullanılmasının engellenmesinin zorunlu olduğu kadar sahte, aldatıcı davranışların engellenmesi de zorunlu olduğu için

8 Tezcan D, Erdem MR ve Önok M, Teorik ve Pratik Ceza Özel Hukuku (18. Bask1, Seçkin Yayıncılık 2020) 1381; Handan Yokuş Sevük, Türk Ceza Hukuku Özel Hükümler (2. Bask1, Adalet Yayınevi 2019) 661; Faruk Erem ve Nevzat Toroslu, Türk Ceza Hukuku Özel Hükümler (5. Baskı, Savaş Yayınları 1987) 206; Faruk Erem, Ümanist Doktrin Açısından Türk Ceza Hukuku Cilt: III (3. Bask1, Seçkin Kitabevi 1985) 519; Soyaslan (n 7) 741.

9 Yener Ünver, İftira - Suç Uydurma - Suç Üstlenme - Yalan Tanıklık ve Suçu İhbar Etmemek Suçları (TCK'da Düzenlenen Adliyeye Karşı Suçlar) (6. Baskı, Seçkin Yayıncılık 2021) 523.

10 Haluk Toroslu, "Suç Uydurma Suçu” (2013) Ankara Barosu Dergisi 71 (1) 323.

11 Gennaro Guadagno, La Simulazione di Reato, Casa Editrice Dott (Eugenio Jovene, Napoli, 1953) 5 (Aktaran Toroslu (n 10) 323).

12 Çetin Özek, “Adliyeye Karşı Suçların Hukuki Konusu” (1997) İstanbul Üniversitesi Hukuk Fakültesi Mecmuası Prof. Dr. Türkan Rado’ya Armağan Sayısı 55 (3) 40.

13 Özek (n 12) 40.

14 Özek (n 12) 40.

15 Özek (n 12) 40; Aynı yönde bkz Ünver (n 9) 187-188. 
bu suçun adliyeye karşı suçlar arasında düzenlenmiş olması yerindedir. Ancak suç uydurma suçunda iftira suçundan farklı olarak uydurulan suçun faili hedef gösterilmemektedir. ${ }^{16} \mathrm{Bu}$ açıdan suç uydurma suçunda korunan hukuki değer en genel anlamda "adliyenin işleyiş düzeni" olarak karşımıza çıkmaktadır. ${ }^{17}$ Doktirndeki bazı görüşlerin aksine kanaatimizce bu suçun yapısı gereği bireylerin adil yargılanma hakkının doğrudan korunduğu söylenemez. ${ }^{18}$ Nitekim bu suç doğrudan kişileri hedef almamaktadır. ${ }^{19} \mathrm{Bu}$ suçta adli makamların gereksiz yere uğraştırılmamasına yönelik bir menfaatin korunması söz konusudur. Adliyenin faaliyetlerini işlevsel olarak yerine getirmesi amacıyla getirilmiş bu düzenleme, dolaylı biçimde adil yargılanmayla ve bireyin hak ve özgürlükleriyle ilişkilendirilebilir. Ancak suç uydurma suçunun kanunda düzenlendiği yer ve kanunun sistematiği göz önünde bulundurulduğunda, adil yargılanma hakkının bu suçla korunan hukuki değer olarak değerlendirilmesi mümkün olamayacaktır. ${ }^{20}$ İlaveten bu suçta korunan hukuki değerin "adliye" olduğu yönünde görüşler de bulunmaktadır. ${ }^{21}$ Kanaatimizce kanun koyucu bu suçta adliyenin işleyiş mekanizmasının sekteye uğramamasını hedeflediği için burada soyut bir niteleme olan adliyeden ziyade somut bir ifadeyle adliyenin işleyiş düzeni korunmaktadır. Nitekim bu suçun kamusal niteliği, bu suçta bireyin adil yargılanma hakkı ile soyut bir nitelik taşıyan adliyenin korunduğu sonucuna ulaşılmasını engellemektedir.

16 Faruk Erem, "Suç Tasnii" (1954) Adalet Dergisi 10 (45) 1180; Y4.CD, 1999/11002E., 1999/11694K., 8.1.1999T.

17 Özbek,Doğan ve Bacaksız (n 3) 1160; Necati Meran, AİHM Kararları ile İçtihatlt-Açıklamalı Basın Yoluyla ve Genel Olarak Hakaret- İftira, Suçtan Kaynaklanan Malvarlığını Aklama, Soruşturmanın Gizliliğini İhlal Suçları (1. Baskı, Seçkin Yayıncılık 2014) 284; Önder (n 5) 269.

$18 \mathrm{Bu}$ suçta korunan hukuki değerin adil yargılanma hakkı olduğu yönündeki görüş için bkz. Ünver (n 9) 186.

19 Erdener Yurtcan, Yargıtay Kararları Işı̆̆ında İftira Suçu (Adliyeye Karşı Diğer Suçlar) (2. Bask1, Türkiye Barolar Birliği Yayınları:303 2015) 52; “...öncelikle iftira ile suç uydurma arasındaki farklara ve her iki suçu birbirinden ayırmakta kullanılacak ölçütün ne olduğuna değinmek gerekmektedir. İftira suçu soruşturma ve kovuşturma başlatılmasını ya da idari bir yaptırım uygulanmasını sağlamak maksadıyla yetkili makamlara ihbar veya şikâyette bulunarak ya da basın yoluyla bir kimseye hukuka aykırı bir fiil isnadıyla işlenirken, suç uydurma ise yetkili makamlara işlenmediğini bildiği bir suçu işlenmiş gibi ihbar ederek ya da bir suçun delil ve emarelerini soruşturma yapılabilecek biçimde uydurarak işlenmektedir. Yani iftira ile suç uydurmayı ayıracak en önemli ölçüt iftira suçunda belli bir kimseye isnatta bulunulması, suç uydurmada ise uydurulan suçun belli bir kimseye isnat edilmemesidir." YCGK, 2014/839E., K. 2018/146K., 3.4.2018T. D.Hilal Kurt, "İftira Suçu (TCK m. 267), Marmara Üniversitesi Sosyal Bilimler Enstitüsü Kamu Hukuku Anabilim Dalı Yayınlanmamış Yüksek Lisans Tezi (2020) 30.

$20 \quad$ Ayn1 yönde bkz. Toroslu (n 10) 324.

21 Bkz. Önder (n 5) 269 ve Tezcan, Erdem ve Önok (n 8) 1381. 
IIIIIIIIII!

\section{TİPİKLİĞİN MADDİ UNSURU}

\section{Fail}

Suç uydurma suçunun faili, işlenmediğini bildiği bir suçu yetkili makamlara işlenmiş gibi ihbar eden ya da işlenmeyen bir suçun delil veya emarelerini soruşturma yapılmasını sağlayacak biçimde uyduran kişidir. Bu bağlamda bu suçun faili özellik arz etmemekte, herhangi bir kişi bu suçun faili olarak değerlendirilebilmektedir. ${ }^{22}$ Ceza sorumluluğunun şahsiliği ilkesi gereği tüzel kişiler suç faili olarak değerlendirilemeyeceği için ${ }^{23}$ suç uydurma suçu tüzel kişiler tarafından işlenemeyecektir. ${ }^{24}$

Kanunda kişilere ihbar yükümlülüğünün yüklenmiş olması, suç uydurma fiilini suç olmaktan çıkarmayacaktır. Örneğin kamu görevlisinin suçu bildirmemesi suçunda da kamu görevlisi fail, işlenmediğini bildiği bir suçu yetkili makamlara işlenmiş gibi ihbar eder ya da işlenmeyen bir suçun delil veya emarelerini soruşturma yapılmasını sağlayacak biçimde uydurursa suç uydurma suçunu işlemiş olduğu kabul edilecektir.

\section{Mağdur}

Suç uydurma suçunda, gerçekte işlenmediği bilinen bir suçla ilgili olarak gereksiz yere bir soruşturma veya kovuşturma başlatılarak, "adliyenin idaresine ait bir varlik veya menfaat ihlal edilmektedir. "' ${ }^{25}$ Doktrinde bir görüşe göre bu suçun mağduru adliyedir. ${ }^{26}$ Diğer bir görüşe göre ise bu suçta ceza yargılamasının yanlış yola sevk edilmesi tehlikesinin engellenmesi amaçlandığı ve bu suretle de kamu adına kanunen ceza yargısının teşkilat ve işlemesinden sorumlu idare olan Adalet Bakanlığı mağdur olarak değerlendirilmelidir. ${ }^{27}$ Kanaatimizce yalnızca gerçek kişiler bir suçta mağdur olabilir. ${ }^{28}$ Tüzel kişiler suçtan zarar gören olarak değerlendirilmelidir. Bu nedenle bu suçta da mağdur, adliyenin işleyişinin aksamadan devam etmesi ve adalet hizmetinin sürekli

22 Önder (n 5) 270; Zeki Hafizoğulları ve Muharrem Özen, Türk Ceza Hukuku Özel Hükümler Millete ve Devlete Karşı Suçlar (1. Baskı, U-S-A Yayıncılık 2016) 150.

23 V. Özer Özbek, Koray Doğan ve Pınar Bacaksız, Ceza Genel Hukuku (Temel Bilgiler), (11. Baskı, Seçkin Yayıncılık 2020) 149.

24 Ünver (n 9) 187; Tüzel kişilerin, cezaların şahsiliği ilkesi gereği cezai sorumluluğun muhattabı olamayacağı ile ilgili bkz. M. Emin Artuk/Ahmet Gökcen/M. Emin Alşahin/ Kerim Çakır, Ceza Hukuku Genel Hükümler (14. Bask1, Adalet Yayınevi 2020) 362-363.

25 Yildirim (n 3) 30.

26 Toroslu (n 10) 325

27 Hafizoğulları ve Özen (n 22) 151.

28 Aynı yönde bkz. Hüsnü Aldemir, Ceza Hukuku Genel Hükümler Rehberi (1. Bask1, Adalet Yayınevi 2019) 181; Fatih Birtek, Ceza Hukuku Genel Hükümler Temel Bilgiler (6. Bask1, Adalet Yayınevi 2018) 203; Tüzel kişilerin de mağdur olarak kabul edilebileceği görüşü için bk. Olgun Değirmenci, “Ceza ve Ceza Muhakemesi Hukukunda Mağdur Hakları” (2008) Türkiye Barolar Birliği Dergisi 21 (77) 39. 
olarak devam etmesi bakımından menfaati bulunan toplumdaki herkestir. ${ }^{29}$ Kaldı ki kabahat veya başka bir idari yaptırım gerektiren hukuka aykırı fiil uydurmaları suç uydurma suçunun kapsamına dahil olmadığ 1 için ${ }^{30}$ devletin yürütme fonksiyonunu yerine getiren idare mağdur olarak değerlendirilemez. ${ }^{31}$

Suç uydurma suçunda belli bir kimse hedeflenmemesine rağmen bu suçtan dolayı bazı kişiler mağdur olarak nitelendirilemeseler bile suçtan zarar görebilirler. Bu kişilerin özel hukuktaki hakları saklı olmak üzere kovuşturma evresinde katılma talepleri mahkemece kabul edilmelidir. ${ }^{32}$ Örnek vermek gerekirse asılsız ihbar neticesinde hedef belirtilmese dahi bir kişinin konutunun arama koruma tedbirine maruz kalması söz konusu olabilir. Bu kapsamda koruma tedbirleri nedeniyle tazminat dahi gündeme gelebilecektir.

\section{Maddi Konu}

Bu suçun maddi konusunu TCK'da veya suç tiplerini düzenleyen başka herhangi bir kanunda suç olarak tanımlanmış bulunan bir fiil oluşturmaktadır. Kanuna göre uydurulan ve ihbar edilen fiilin suç teşkil etmesi gerektiğinden, disiplin cezas1 gerektiren fiiller ile idari yaptırım ${ }^{33}$ öngörülen kabahat fiilleri suç uydurma suçunun konusunu oluşturamayacaktır. ${ }^{34}$ Suç uydurma suçunda failin yetkili makamlara bildirdiği ya da soruşturma yapılmasını sağlayacak şekilde delil veya emarelerini uydurduğu fiil teknik anlamda adli bir suçtur. Ancak iftira suçunda yetkili makamlara ihbar edilen fiil suç teşkil edebileceği gibi idari bir yaptırım gerektiren hukuka aykırı bir fiil olarak da belirebilir. ${ }^{35}$ Kanun koyucu birbiri ile oldukça benzeyen iki suç tipinde böylesi bir farklılığın gerekçesini belirtmemiştir. Kanımızca idari bir yaptırım gerektiren

\section{Dündar, "İftira Suçu ile Benzeri Suçlar üzerine Bir İnceleme" (1984) Adalet Dergisi 75} (2) 310 .

34 Hafizoğulları ve Özen (n 22) 152; A. Selçuk Sönmez, Türk Ceza Kanunu'nda İftira Suçu (1. Bask1, Hakim Yayınları 2016) 67; Parlar ve Hatipoğlu (n 2) 4262; A.Tolgahan Serttaş, Türk Ceza Kanunu'nda İftira Suçu (TCK m. 267), Akdeniz Üniversitesi Sosyal Bilimler Enstitüsü Kamu Hukuku Anabilim Dalı Yayınlanmamış Yüksek Lisans Tezi (2018) 29; 765 sayılı TCK m. 285/7 ile uydurulan fiilin suç değil de kabahat teşkil etmesi durumunda hükmolunacak cezanın yarı oranında indirilmesi hükmolunmuştur. Ancak 5237 sayılı TCK m. 271'de kabahat teşkil eden fiilin uydurulması indirim sebebi olarak öngörülmemiştir. "2003 yılında "Hükümet Tasarısı" olarak TBMM’ye sunulmuş olan Tasarının 434. maddesinde, disiplin suçlarına ilişkin asılsız ihbar ve uydurmaların da bu suça vücut vereceği hükme bağlanmıştı. Benzer düzenleme, 1997 TCK Tasarısı'nın 432. maddesinde yer almıştı.” Yıldırım (n 3) 119; Erem (n 8) 521.

35 Y1ldırım (n 33) 179; Dündar (n 33) 310. 
IIIIIIIIIII

fiiller adli suç kapsamında değerlendirilemeyeceği ve adli makamlar idari yaptırımı araştırma bakımından kural olarak yetkili olmadığından suç uydurma gündeme gelmeyecektir. Bu kapsamda da idari yaptırım gerektiren uydurma fiil ihbarında maddi konu unsuru gerçekleşmeyecektir.

Bu suçta ihbar edilen ya da delil veya emareleri uydurulan fiil işlenmemiş bir suç teşkil etmektedir. ${ }^{36}$ Ancak burada önem arz eden bir husus bulunmaktadır. Eğer fail suç uydurduktan yani fiili işledikten sonra uydurmaya konu edilen fiil artık suç olarak düzenlenmemiş; yani kanun değişikliği ile uydurulan fiil suç olmaktan çıkarılmışsa fail suç uydurma suçunu işlemiş olacak mıdır ya da işlediği kabul edildiğinde bu fiilden cezalandırılabilecek midir? Nitekim suçun maddi konusunu varlık kabiliyetini artık haiz değildir. Burada failin suç uydurması ile suçun koruduğu hukuki değer bağlamında gerçekleşmemesini beklediği adliye açısından tehlike veya zarar, suçun uydurulmasıyla zaten gerçekleşmiştir. ${ }^{37}$ Fail hukuk düzenini, kanun değişikliğinden önce ihlal etmiştir. Söz konusu kanun değişikliği, suç uyduran failin lehine veya aleyhine bir sonuç doğurmayacaktır. Nitekim bu suçla korunan hukuki değer ihlal edilmiş, adliyenin işleyişi tehlikeye sokulmuştur. Aynı şekilde suç uydurulduktan sonra ihbar edilen ya da delil veya emareleri uydurulan fiilin genel af kapsamına alınması durumunda da aynı sonuca varılmalıdır. Ancak dikkat edilmesi gereken nokta, uydurma fiilinden önce uydurulan suçun artık suç olarak düzenlenmemiş veya af kapsamına alınmış olması gereğidir. ${ }^{38}$ Ayrıca belirtmek gerekir ki failin uydurduğu suçun ne zaman işlendiğini belirttiği ihtimallerle de karşılaşılabilir. Şöyle ki fail suçun uzun bir zaman önce işlendiğini belirtmesi, adli makamlarca da yoğun bir araştırma yapılmasını gerektirmeyecek şekilde ilk bakışta uydurulan suçun hali hazırda dava zamanaşımına uğradığı da anlaş1lıyorsa bu suçun takibat imkânı bulunmayacaktır. ${ }^{39} \mathrm{Bu}$ bağlamda korunan hukuki değer bağlamında adliyenin işleyiş düzeni tehlikeye girmeyeceği için suç uydurma suçundan da bahsedilemeyecektir.

Son olarak bahsedilmesi gereken husus uydurulan suçun niteliğidir. Kanun koyucu sadece "suç"tan bahsettiği için burada suçun niteliği önem arz etmeyecektir. Söz konusu suçun kasten yahut taksirle işlenebiliyor olması, kalkışma suçu $\mathrm{u}^{40}$ niteliğinde olması, teşebbüs aşamasında kalan bir suçun uydurulması TCK m. 271 için önem arz etmemektedir. ${ }^{41}$

36 Suç uydurma suçunda, iftira suçundan farklı olarak delilleri uydurulan ya da yetkili makamlara ihbarda bulunulan suç, işlenmemiş olmalıdır. İftira suçunda masum kişiye isnat edilen hukuka aykırı fiilin gerçekte işlenmiş olup olmaması önemli değildir. Önemli olan, o fiilin, isnat edilen kişi tarafından işlenmemiş olmasıdır. Yıldırım (n 33) 179; Dündar (n 33) 309.

37 Toroslu (n 10)332.

38 Toroslu (n 10) 332.

39 Erem (n 8) 522.

40 Kalkışma suçlarıyla ilgili bkz. Timur Demirbaş, Ceza Hukuku Genel Hükümler (15. Bask1, Seçkin Yayıncılık 2020) 254.

41 Özbek, Doğan ve Bacaksız (n 3) 1160; Soyaslan (n 7) 741. 


\section{Fiil}

$\mathrm{Bu}$ suçun fiil unsurunu, işlenmediği bilinen bir suçun yetkili makamlara işlenmiş gibi ihbar edilmesi ya da işlenmeyen bir suçun delil veya emarelerinin soruşturma yapılmasını sağlayacak biçimde uydurulması oluşturmaktadır. ${ }^{42} \mathrm{Bu}$ suç, ihbardan yetkili makamların haberdar olduğu anda veya işlenmeyen suçun delil veya emarelerinin soruşturma yapılmasını sağlayacak şekilde uydurulması anında tamamlandığından ani suç olarak değerlendirilir. Soruşturma veya kovuşturma yapılması ve herhangi bir zararın vuku bulması aranmadığı için bu suç bir zarar suçu da değildir. Suç uydurma suçunun işlenmesi ile adliyenin yanıltılması tehlikesi cezalandırılır; ancak kanun burada tehlikeyi somutlaştırmadığı için bu suç bir soyut tehlike suçudur. Kanunda düzenlenen her iki seçimlik hareketin de soyut bir tehlike ihtiva ettiği kanaatindeyiz. Ancak doktrinde bir görüşe göre maddi suç uydurma niteliğindeki ikinci fikrada düzenlenen hareketin somut bir tehlike ihtiva ettiği savunulmaktadır. Öyle ki uydurulan delil veya emarelerin soruşturma açılması tehlikesi yaratacak elverişlilikte olması somut bir tehlikeyi ihtiva etmektedir. ${ }^{43}$ Ancak kanaatimizce soruşturma açılmasına elverişli delil veya emare uydurulması somut bir tehlike oluşturmamaktadır. Somut tehlike suçlarında suç konusunun somut ve belirli olarak tehlikeye sokulması söz konusudur. ${ }^{44} \mathrm{Bu}$ suçlarda suçun konusunun zarara uğratılma ihtimali ve tehlikesi netice olarak tanımlanmıştır. ${ }^{45}$ Maddi uydurma teşkil eden harekette tehlike yaratan husus soyut olarak adli makamların gereksiz yere meşgul edilmesidir. Burada konunun somut olarak tehlike oluşturan bir neticeye bağlanmadıği gerekçesi ile bu hareketin somut değil soyut tehlike suçu teşkil ettiği kanaatindeyiz.

42 "Iftira suçunun oluşabilmesi için failin yetkili makamlara ihbar veya şikayette bulunarak işlemediğini bildiği halde, hakkında soruşturma ve kovuşturma başlatılmasını ya da idari bir yaptırım uygulanmasını sağlamak için bir kimseye hukuka aykırı bir fiil isnat etmesi gerektiği, somut olayda; saniğın isim vermeden ve belirli bir kişiye isnatta bulunmadan faili meçhul kişi veya kişilerin kendisi adına cep telefonu hattı alarak kullandıklarını beyan ederek Cumhuriyet savcılığına ihbar ve şikayette bulunmaktan ibaret eyleminin suç uydurma suçunu oluşturacağı hukuki durumunun buna göre takdir ve tayini gerektiği gözetilmeden; suç vasfinda yanılgıya düşülerek iftira suçundan mahkumiyet hükmü kurulması, SONUÇ: Kanuna aykırl, sanığın temyiz itirazlarl bu nedenlerle yerinde görülmüss olduğundan, hükmün bu sebepten dolayı BOZULMASINA, 1412 sayll CMUK'nın 326 /son maddesi gereğince ceza miktarı bakımından kazanılmış hakkının saklı tutulmasina, 09.03.2015 tarihinde oybirliğiyle karar verildi."’Y16.CD, 2015/66E., 2015/15K., 9.3.2015T. Serttaş (n 34) 28.

43 Ünver (n 9) 190; Aynı yönde bkz. Yokuş Sevük (n 8) 662.

44 Heinrich B, Ceza Hukuku Genel Kısım - I (Cezalandırılabilirliğin Temel Esasları Tamamlanmış ve Teşebbüs Edilen Suçlarda Suçun Yapısı), (Ed. Yener Ünver) (1. Baskı, Adalet Yayınevi 2014) 93.

45 Hamide Zafer, Ceza Hukuku Genel Hükümler (TCK m.1-75) (7. Bas1, Beta Yayıncılık 2019) 239. 
IIIIIIIIII!

Doktrinde bu suçun fiili, "şekli suç uydurma" ve "maddi suç uydurma" olarak ikiye ayrılmıştır. ${ }^{46}$ Seçimlik hareketlerden ilkini ifade eden şekli suç uydurma fiili ile işlenmeyen bir suçun ihbar edilmesi; maddi suç uydurma fiili ile ise delillerin ya da emarelerin uydurulmasını temsil etmektedir. Bu iki hareketten birinin gerçekleştirilmesiyle suç oluşmaktadır. Bu hareketlerin ikisi birden gerçekleştirilse dahi ortada tek bir suç söz konusu olacaktır. ${ }^{47}$ Ancak hâkim, TCK m. 61 hükümleri uyarınca cezada üst sınıra yaklaşacaktır. ${ }^{48} \mathrm{Bu}$ kapsamda hareketlerden her birini ayrı ayrı incelemek gerekmektedir.

\section{1. İşlenmediği Bilinen Bir Suçun Yetkili Makamlara İşlenmiş Gibi İhbar Edilmesi (Şekli Suç Uydurma)}

Bu hareket bağlamından işlenen fiilin suç uydurma suçunu teşkil edebilmesi için suç ihbarının belirli bir kişiye yönelik olarak suç isnad etme suretiyle yapılmamış olması gerekir. ${ }^{49}$ Nitekim belirli bir kişi hedef alınarak yapılan uydurma suç isnadı iftira suçu teşkil edecektir. ${ }^{50}$ Ancak kanun koyucu ihbarın hangi şekilde yapılması gerektiği hususunu somutlaştırmamıştır. Suçun oluşabilmesi için ihbarın yetkili mercileri harekete geçirebilme kabiliyetini haiz olması gerekmektedir. Bu husus "takibat imkânı" olarak adlandırılmaktadır. ${ }^{51}$

Takibat imkânına sahip olmayan suç uydurmaları elverişsiz teşebbüs kapsamında değerlendirilmelidir. Nitekim suçun takibat imkânına sahip olmaması, suçun maddi konusunun elverişsizliği sonucunu doğurmaktadır. Elverişsiz teşebbüste (işlenemez suç) suçun konusu üzerinde gerçekleştirilmek istenen neticenin gerçekleşme imkânı kalmamıştır. ${ }^{52} \mathrm{Bu}$ da suçun tipikliğinin gerçekleşmesini engelleyecektir. ${ }^{53}$ Tipiklik gerçekleşmediğinde de failin cezalandırılması söz konusu olmayacaktır.

46 Parlar ve Hatipoğlu (n 2) 4261; Bu ayrımın gereksiz olduğu görüşü için bkz. Ünver (n 9) 188.

47 Hafızoğulları ve Özen (n 22) 153; Erem ve Toroslu (n 8) 209.

48 "Dosya kapsamına göre, sanık hakkında hüküm kurulurken TCK.nın 61. maddesi uyarınca yasal gerekçelerle alt sinırdan uzaklaşılmasında bir isabetsizlik yok ise de; 5237 sayılı TCK.nın 3. maddesinde yer alan "suç işleyen kişi hakkında fiilin ă̆ırlığıyla orantılı cezaya hükmolunur" şeklindeki orantılllık ilkesi ile hak ve nesafet kurallarl gözetilmeden, eyleminde suçun işleniş biçimi, işlendiği yer ve zaman, suç kastının önem ve değeri, meydana gelen zarar ve tehlikenin ăgırlı̆̆l, failin kastına dayalı kusurunun ă̆ırlığl, failin güttüğ̈̈ amaç ve saik bakımından bir özellik arzetmeyen sanık hakkında yazılı şekilde fazla ceza tayini, yasaya aykirl..."Y8.CD, 2018/2355E., 2020/14211K., 25.6.2020T.

49 Parlar ve Hatipoğlu (n 2) 4261; Serttaş (n 34) 28; Soyaslan (n 7) 742.

50 Artuk ME, Gökcen A, Alşahin ME ve Çakır K, Ceza Hukuku Özel Hükümler (19. Bask1, Adalet Yayınevi 2021) 1171.

$51 \quad$ Erem ve Toroslu (n 8) 206.

52 Uğur Alacakaptan, Suçun Unsurları (1. Baskı, Sevinç Matbaası 1970) 31.

53 Elverişsiz teşebbüs kavramı ile ilgili bkz. Gözde Kazaker, "Elverişsiz Teşebbüs ve Mefruz Suç Ayrımı" (2020) Sosyal Bilimler Araştırma Dergisi 9 (1) 129 vd. 
Herhangi bir biçimde suçun takip edilmemiş olması bu suçun oluşmasını engellemeyecektir. İlaveten ihbarın uydurma olduğu ilk bakışta anlaşılmaktaysa bu suç söz konusu olmayacaktır. ${ }^{54}$ Nitekim CMK m. 158/6 hükmüne göre "İhbar ve şikâyet konusu fiilin suç oluşturmadığının herhangi bir araştırma yapılmasını gerektirmeksizin açıkça anlaşılması veya ihbar ve şikâyetin soyut ve genel nitelikte olması durumunda soruşturma yapılmasına yer olmadiğına karar verilir. Bu durumda şikâyet edilen kişiye şüpheli sıfatı verilemez.” Her ne kadar suç neticesinde soruşturma açılması zorunlu değilse de cumhuriyet savcısının bu hükme göre soruşturmaya yer olmadığı kararı vermesi durumunda suç uydurma suçuyla korunan hukuki değer bağlamında adliyenin meşgul edilmediği kanaatindeyiz. Bu sebeple ihbar edilen suçun veya uydurulan delil veya emarelerin ilk bakışta iğfal kabiliyetini haiz olmaması karşısında suç uydurma suçunun oluştuğu savunulamaz. Nitekim kamu düzenini ilgilendiren bu suçta iğfal kabiliyetinin olmayışı sonucunda kamusal değerler tehlike altına girmeyecektir. Ancak şüpheli hakkında Cumhuriyet savcıllğınca kovuşturmaya yer olmadığı kararı (takipsizlik) verilmişse takibat imkânı şartı gerçekleşmiş sayılmalıdır. ${ }^{55}$ Nitekim burada Cumhuriyet savcısı, suçun kovuşturulabilirliği bağlamında bir araştırma faaliyetine girişmiş, emek ve mesai harcamıştır. Burada suç uydurma suçunun soyut tehlike suçu olmasının etkisi söz konusudur. Adli faaliyetin işleyişi tehlikeye sokulduğu için takipsizlik kararı verildiğinde tipiklik gerçekleşmiş sayılmalıdır.

İhbarla ilgili önemli olan başka bir husus da ihbarın gerçek bir durumu temsil etmemesi gereğidir. İhbar dilekçesinde imzanın bulunması şart olmadığı gibi imzanın sahte olması da önemli değildir. ${ }^{56}$ Dilekçede imzanın bulunmaması, fiilin iğfal kabiliyetini haiz olmadığı anlamına gelmeyecektir.

Suçun ihbarda doğru olarak nitelendirilip nitelendirilmediğinin veya ihbarın içeriğinin açık olup olmamasının da önemi bulunmamaktadır. Örneğin ihbar edenin açık kimliği veya imzası bulunmasa yahut uydurulan fiil yanlış değerlendirilip başka bir suç nitelemesinde bulunulsa dahi ihbarda bulunma fiili vuku bulmuş sayılacaktır. Nitekim suç uydurma suçu re'sen soruşturulur. Bu kapsamda da Cumhuriyet savcısı CMK m. 160 gereği gerçeği araştırmakla yükümlüdür. Ayrıca ihbarın kendiliğinden veya yetkili makamların daveti üzerine yapılmış olup olmaması önem arz etmemektedir.

Doktrinde soruşturulması ve kovuşturulması şikayete bağlı olan suçların uydurulmasında, suç uydurma suçunun oluşup oluşmayacağ hususu tartışmalıdır. Kanun hükmü incelendiğinde yalnızca "ihbar"dan söz edildiği görülmektedir. İftira suçundaysa "ihbar veya şikayet”ten açıkça söz

\footnotetext{
54 Erem ve Toroslu (n 8) 207.

55 Erem (n 8) 519.

56 Erem (n 8) 521.
} 
IIIIIIIIII!

edilmektedir. Doktrinde çoğunluğun görüşüne göre, madde metninde sadece ihbardan bahsedildiği, "şikayet”ten söz edilmediği için şikayete bağlı suçların uydurulmasında bu suç oluşmayacaktır. İhbarda bulunma fiili ile, işlendiği iddia edilen suçun re'sen soruşturulan ve kovuşturulan bir suç olması aranmıştır. ${ }^{57}$ Doktrinde diğer bir görüş ise kanun metninde geçen bu "ihbar" sözcügünü, teknik anlamda anlaşılmaması ve bu kavramın dar yorumlanmaması gerektiğini savunmaktadır. ${ }^{58} \mathrm{Bu}$ bakımdan, suçu soruşturmakla görevli makamları harekete geçirmeye yönelik her çeşit beyan arasında "şikâyet" de yer almaktadır. ${ }^{59}$ Diğer bir görüşse CMK m. 158/7 uyarınca şikayet bulunmasa dahi şikayete tabi suç hakkında kamu davasının yürütülmesi mümkün olduğundan ${ }^{60}$ şikayet şartı gerçekleşmese dahi suç uydurma suçu işlenebilecektir. ${ }^{61}$ Ancak kanaatimizce kanun burada suçun oluşması için ihbar fiilini aramaktadır. İhbar ise re'sen soruşturulan suçlarda yetkili makamların bilgilendirilmesidir. Nitekim kanun koyucu CMK m. 158 hükmünde ihbar ve şikayeti birbirinden ayırarak düzenlemiştir. TCK m. 271'de de suçun ihbar ile işlenebileceği belirtilmiştir. Eğer suç uydurma suçunun şikayet ile de işlenebileceği kabul edilirse bu durum kanunilik ilkesi bağlamında kıyasa yol açacak şekilde genişletici yorum yasağına aykırılık teşkil edecektir.

İşlenmemiş suçun belli bir kişiye izafe edilerek ihbar edilmesi fiili, suç uydurma suçunu değil iftira suçunu oluşturacaktır. ${ }^{62}$ Burada ayrım noktasını,

57 Parlar ve Hatipoğlu (n 2) 4262; Erem ve Toroslu (n 8) 207; Erem (n 16) 1180; Meran (n 17) 296; Serttaş (n 34) 29.

58 Özbek, Doğan ve Bacaksız (n 3) 1161; Yıldırım (n 3) 117.

59 Tezcan, Erdem ve Önok (n 8) 1382; Yıldırım (n 3) 117; Doktrinde Soyaslan'a göre, ihbar edilen fiil şikayete tabi ve bu şart da gerçekleşmemişse soruşturma başlayabilmesi mümkün olmayacağından kamusal yarar tehlikeye girmeyecek, adliye aldatılamayacak, bu suretle de suç uydurma suçu oluşmayacaktır. Soyaslan (n 7) 742.

60 CMK m. 158/7: "Yürütülen soruşturma sonucunda kovuşturma evresine geçildikten sonra suçun şikâyete bağlı olduğunun anlaşılması halinde; mağdur açıkça şikâyetten vazgeçmediği takdirde, yargilamaya devam olunur."

${ }_{61}$ Yaşar, Gökcan ve Artuç (n 7) 7920.

62 Erem ve Toroslu (n 8) 207; Parlar ve Hatipoğlu (n 2) 4262; Köksal Bayraktar, "İftira" (1974) İstanbul Üniversitesi Hukuk Fakültesi Mecmuası 40 (1-4) 185; Yıldırım (n 33) 179, 188; Ünver (n 9) 196; "Sanı̆̆ın, Cumhuriyet Başsavcıllğına başvurarak kendisinden tahsil edilen borcu için yeniden icra takibi yapılması nedeni ile borcu ödediği ve borcun ödendiği şeklinde belge veren kişilerden şikayetçi olduğu olayda, sanığın iddiasındaki avukatın belirlenebilir nitelikte olması nedeniyle sanığın yetkili makamlara şikayette bulunarak işlemediğini bildiği halde, soruşturma ve kovuşturma başlatılmasını sağlamak amacıyla hukuka aykırı bir fiil isnat etme eyleminin iftira suçunu oluşturduğu gözetilmeden suç vasfinda hataya düşülerek yazıl ş̧ekilde hüküm tesisi, kanuna aykırı... "Y8.CD, 2019/784E., 2020/17636K., 27.10.2020T; TCK m. 167'de sayılan akrabalar tarafından birbirleri arasında suç uydurma fiilinin işlenmesi durumunda doktrinde tartı̧̧ma konusu olmuştur. Ancak burada hırsızlık suçu işlediği belirtilen akraba ismen veya ima yoluyla belirtildiğinde suç uydurma suçu değil iftira suçunun oluşacağı açıktır. Erem ve Toroslu (n 8) 207. 
gerçekte olmayan bir kişiye suçun izafe edilmesi oluşturmaktadır. Suç uydurma suçundan bahsedebilmek için ihbarda belirtilen suçun belirli bir kimse tarafından değil, belirli olmayan kişilerce işlendiği ve işlendiği iddia edilen fiilin failinin bilinmediği ifade edilmelidir. ${ }^{63}$ İlaveten belirli bir kişi ne açıtan ne de zımnen hedef gösterilmiş olmalıdır. ${ }^{64}$

Doktrinde ölmüş bir kimseye işlemediği bir suçun isnat edilmesi halinde de suç uydurma suçunun gündeme gelebileceğini savunan görüşler bulunmaktadır. ${ }^{65}$ Bu görüşe göre, ölmüş kimsenin suç işlemesi ihtimal dahilinde olmadığı için iftira suçu işıenmemiş sayılacaktır. Ancak yetkili makamların gereksiz yere meşgul edilmesi tehlikesi devam edecektir. Ancak üzerine suç isnad edilen kişinin öldüğ̈nün herkes tarafindan bilindiği durumlarda (örnek vermek gerekirse ünlü birinin öldüğü herkesçe bilinecektir), uydurulan suça ilişkin ihbar yetkili makamları harekete geçirmeye elverişli olmayacak ve suç uydurma suçu gündeme gelmeyecektir. ${ }^{66}$ Ancak bu görüş suç uydurma suçunun teknik yapısıyla bağdaşacak nitelikte değildir. Suç uydurma suçunda uydurulan suçun failini belirlemeye yönelik bir isnatta bulunulmaması gerekmektedir. Ölü bile olsa bu suçla kimse hedef gösterilemez. Doktrinde bahsedilen bu ihtimalde iftira suçundan söz edilemeyecek; ancak suç uydurma değil, ölen kişinin hatırasına hakaret suçu (TCK m. 130) söz konusu olacaktır. ${ }^{67}$

Gerçek durumu yansıtmayan ihbarların yetkili makamlara yapılmış olması gerekmektedir. ${ }^{68}$ İhbar ve şikayetlerin yapılabileceği yetkili makamlar CMK m. 158'de belirtilmiştir. Bu maddeye göre: "(1) Suça ilişkin ihbar veya şikâyet, Cumhuriyet Başsavcılı̆̆ına veya kolluk makamlarına yapılabilir. (2) Valilik veya kaymakamliğa ya da mahkemeye yapılan ihbar veya şikâyet, ilgili Cumhuriyet Başsavcılığına gönderilir. (3) Yurt dışında işlenip ülkede takibi gereken suçlar hakkında Türkiye'nin elçilik ve konsolosluklarına da ihbar

63 Artuk ME, Gökcen A ve Yenidünya C, Ceza Hukuku Özel Hükümler (15. Bask1, Adalet Yayınevi 2015) 1158; Parlar ve Hatipoğlu (n 2) 4263.

64 Kurt (n 19) 30; Erem ve Toroslu (n 8) 207; "Sanığın, mağdurun kendisine tokat attı̆̆ını ve hakaret ettiğini, ayrica olay yerinde bulunan köylüler tarafindan taş atılmak suretiyle aracının camının kırıldiğg beyanları dikkate alındiğında eyleminin bir bütün olarak TCK. nın 267/1, 43/1. maddelerinde yer alan iftira suçunun oluşturduğu gözetilmeden, sanık hakkında suç uydurma ve iftira suçundan ayrı ayrı hüküm kurulması, bozmayı gerektirmiş..." Y8.CD, 2020/3246E., 2020/17147K., 19.10.2020T.

"Sanı̆̆ın sonraki ifadelerinde bu kişinin ... olduğuna dair beyanları karşısında failin belirlenebilir nitelikte olması nedeniyle Mahkemece suç vasfinda hataya düşülerek iftira suçu yerine suç uydurma suçundan hüküm kurulması, yasaya aykırı...” Y8.CD, 2019/1606 E., 2020/16849K., 12.10.2020T.

65 Bkz. Önder (n 5) 273.

66 Antonio Pagliaro, Principi di Diritto Penale, (par. spec., Giuffre, Milano 2000) 65 (Aktaran Toroslu (n 10) 325).

67 Toroslu (n 10) 325.

68 Önder (n 5) 271. 
IIIIIIIIIII

veya şikâyette bulunulabilir. (4) Bir kamu görevinin yürütülmesiyle bağlantılı olarak işlendiği iddia edilen bir suç nedeniyle, ilgili kurum ve kuruluş idaresine yapılan ihbar veya şikâyet, gecikmeksizin ilgili Cumhuriyet Başsavcılığına gönderilir." İhbar veya şikâyet yazılı veya tutanağa geçirilmek üzere sözlü da olarak yapılabilmektedir (CMK m. 158/5). Yapılan sözlü ihbarlar bir tutanağa geçirilir. ${ }^{69}$

İhbarların söz konusu maddede belirtilen yetkili mercilere değil de "basında veya bir yayın organinda yer alan bir hususun yetkili makamlarca ihbar kabul edilip kovuşturmaya geçilmesi durumunda" suç uydurma suçu oluşmayacaktır. ${ }^{70}$ Nitekim kanunda failin yetkili makamları harekete geçirecek şekilde ihbarda bulunması aranmaktadır. İlaveten Cumhuriyet savcısı tarafından basın yayın yoluyla öğrenilen suç uydurma fiili neticesinde uydurulan suçun re'sen soruşturulması da kanaatimizce suç uydurma suçunu teşkil etmeyecektir. Çünkü Kanun failin yetkili makamları harekete geçirecek şekilde ihbarda bulunması fiilini aramaktadır. Ancak doktrinde işlenmediği bilinen bir suçla ilgili olarak yapılan ihbarların suç uydurma suçunu teşkil edebilmesi için, sadece yetkili makamlara yapılması gerektiği koşulunun tartışmalı olduğunu savunan görüşler bulunmaktadır. ${ }^{71} \mathrm{Bu}$ görüşe göre, soruşturma mercilerinin basını sürekli takip ettiğinin farkında olan failin, doğrudan yapması gereken ihbarı, basın yolu ile yapması durumunda dolaylı ancak gerçekte doğrudan olan ihbarı cezasız kalmaktadır. ${ }^{72}$ Ancak kanun koyucu, "basin yayın yolu" ile yapılan suç uydurma teşkil eden ihbarları suç olarak düzenlemek isteseydi, iftira suçunda ayrıca belirttiği üzere bunu ilgili maddede açıkça belirtirdi. ${ }^{73}$

69 Nevzat Toroslu ve Metin Feyzioğlu, Ceza Muhakemesi Hukuku (19. Baskı, Savaş Yayınları 2019) 306.

70 Tezcan, Erdem ve Önok (n 8) 1383; Meran (n 17) 297; Ünver (n 9) 193; Parlar ve Hatipoğlu (n 2) 4263; Doktrinde Erem, ihbarın teknik olarak anlaşılmaması gerektiğini, adi makamları harekete geçirecek her türlü beyanın bu suç kapsamında ihbar olarak değerlendirilmesi gerektiği savunmaktadır (Erem (n 8) 521). Ayrıca Doktrinde her ne kadar uygulamada görülme ihtimali son derece düsük olsa da, teorik açıdan suç uydurmanın "talep" veya "başvuru" yoluyla işlenmesi de mümkün olduğuna ve dair görüşler bulunmaktadır (Toroslu (n 10) 326). İlaveten suç uydurmanın başvuru yoluyla da işlenmesin mümkün olduğu, belli suçlarda belli devlet makamları dava açmayı zorunlu kılmayacak şekilde şikayette bulunduklarında (örneğin 6362 sayılı Sermaye Piyasası Kanunu'nda olduğu gibi) da ihbar şartının gerçekleştiği savunulmaktadır. Ancak Kanunun lafzı açıktır. İhbar kavramını şikayeti de içine alacak şekilde genişletmenin suç ve ceza içeren hükümlerde kıyasa yol açacak genişletici yorum yasağına aykırılık teşkil edeceği bu sebeple de ihbarın bu suç kapsamında CMK m. 158 özelinde teknik olarak değerlendirilmesi gerektiği kanaatindeyiz. Nitekim her türlü suç bildirimini ihbar kavramı içinde mütalaa etmek, kişilerin cezalandırılabilme alanını genişletecek, özgürlük alanını daraltacaktır.

71 Yildırım (n 3) 118.

72 İsmail Malkoç, Açıklamalı Türk Ceza Kanunu 4. Cilt (1. Baskı, Yazarın Kendi Yayını 2013) 4654.

73 Aynı yönde bkz. Yıldırım (n 3) 118. 
Nitekim kanunilik ilkesi gereği, yetkili mercilerce suç uydurmalarının dolaylı olarak öğrenilmesi, suç uydurma suçunu teşkil etmeyecektir.

Gerçekte işlenmiş bir suçun niteliği farklı gösterilip fiil ihbar edildiğinde suç uydurma suçunun oluşup oluşmadığının da tartışılması gerekmektedir. Burada fail gerçekte işlenen suçun niteliğini biliyor ancak buna rağmen suçu soruşturmakla yetkili organları gereksiz yere meşgul edecek biçimde vakıayı bilerek ve isteyerek çarpitıyorsa bu halde suç uydurma suçunun işlendiğini kabul etmek gerekir. ${ }^{74}$

Son olarak işlenmediği bilinmesine rağmen işlendiği iddia edilen suçun tamamlanmış olması ya da teşebbüs aşamasında kalması, suç uydurma suçunun oluşması bakımından önemli değildir. ${ }^{75}$ Ayrıca işlendiği iddia edilen suç için öngörülen cezai yaptırımın hapis veya adli para cezası olarak öngörülmesi de suç uydurma suçunun oluşması bakımından önem arz etmemektedir.

\section{2. İşlenmeyen Bir Suçun Delil veya Emarelerinin Soruşturma Yapılmasını Sağlayacak Biçimde Uydurulması (Maddi Suç Uydurma)}

Söz konusu seçimlik hareketi incelemeden önce delil ve emare kavramlarının açıklanması gerekmektedir. Delil, mevcut bir suça ilişkin olarak maddi vakıayı yahut bu vakıanın bir parçasını yansıtan, suç sanıklarının tespitine yarayan her türlü ispat vasıtasıdır. ${ }^{76}$ Emare ise delil niteliği bulunmayan mevcut bir suça ilişkin belirti ve izdir. ${ }^{77}$

Türk Ceza Kanunu'nda yer alan; iftira suçunda "failin maddi eser ve delilleri", suç uydurma suçunda "bir suçun delil ve emareleri", tutuklu hükümlü veya suç delillerini bildirmeme suçunda (TCK m. 248/2) ise "işlenmiş olan bir suça ilişkin delil ve eserlerin", suç delillerini yok etme, gizleme veya değiştirme suçunda (TCK m. 281) sadece "delil" ifadeleri kullanılmıştır."7 Kanımızca kanun koyucu burada her suç tipini özelinde değerlendirerek farklı belirleme yoluna gitmiştir. Nitekim beyan, belge, belirti (emare) niteliğinde olan ceza muhakemesinde maddi gerçeğe ulaşılmasını sağlayan her şey delildir. ${ }^{79}$

Maddi uydurma fiili, işlenmeyen bir suçun delil veya emarelerinin soruşturma yapılmasını sağlayacak biçimde uydurulmasıdır. Maddi suç uydurmada suçun tamamlandığ 1 an hususu tartışmalıdır. Bir görüşe göre işlenmeyen suçun delil veya emareleri soruşturma yapılmasını sağlayacak

\footnotetext{
Özbek, Doğan ve Bacaksız (n 3) 1162.

Ünver (n 9) 189-190.

Artuç (n 30) 1410; Yaşar, Gökcan ve Artuç (n 7) 7921.

Yaşar, Gökcan ve Artuç (n 7) 7921; Artuç (n 30) 1410.

78 Mahmut Koca ve İlhan Üzülmez, Türk Ceza Hukuku Özel Hükümler (6. Baskı, Seçkin Yayınları 2019) 1000.

79 Koca ve Üzülmez (n 78) 1001.
} 
IIIIIIIIII!

biçimde uydurulduğunda uydurulan delil ve emarelerin yetkili makamlarca bulunması yahut uydurulan delil veya emarelerin yetkili merciin bilgisine ulaşmasıyla suç tamamlanmaktadır. ${ }^{80}$ Ancak bu suçta kanun, suçun işlenmiş sayılması için soruşturmaya başlanmış olmasını aramadığından delil veya emare uydurmakla suç tamamlanmış sayılmalıdır. ${ }^{81}$

Maddi suç uydurma fiilinde failin yetkili makamlara ihbarda bulunup bulunmaması ve soruşturmaya başlanıp başlanmaması önem arz etmemektedir. Önem arz eden husus failin işlenmeyen bir suçun delil veya emarelerinin uydurulmasının yetkili makamları harekete geçirmeye elverişli olmasıdır. Şekli suç uydurma bağlamında elverişsiz teşebbüs ile ilgili değerlendirmelerimiz burada da aynen geçerli olacaktır.

Uydurulan delil veya emarelere ilişkin fiilin vuku bulmamış olması gerekmekle birlikte bu fiile eklemelerin yapılması, bu fiillerin abartılmas1 ya da fiilin bütünüyle uydurulmuş olması, maddi suç uydurma bakımından önemli değildir. ${ }^{82}$ İlaveten uydurulan fiilin geçmişte gerçekleşmiş olması ya da günümüzde gerçekleşmesi de önem arz etmemektedir. Eğer gerçekte işlenmiş bir suça ilişkin başlatılan soruşturmayı delil uydurmak suretiyle yanlış yönlendirme söz konusu ise bu durumda suç uydurmadan değil "suç delillerini yok etme, gizleme veya değiştirme suçunu (TCK m. 281)" "83 oluşturmaktadır. ${ }^{84}$

Bir suçun işlendiği izlenimi uyandıran her türlü "maddi delil veya emare" suçun eseri niteliği taşır. ${ }^{85}$ Uydurulan suçun eserleri ilk bakışta suçun uydurulduğunu, yani gerçekleşmediğini gösterir nitelikteyse suç uydurma suçu oluşmaz. Ayrıca uydurulmuş olan eserler, kanunlarda düzenlenen herhangi bir suçun işlendiğini gösterir nitelikteyse kovuşturma evresine geçilmese dahi suç uydurma suçundan bahsedilebilecektir. Eğer bu fiiller suç teşkil etmiyorsa (örneğin intihar etme, teşebbüs aşamasına varmayan hazırlık hareketleri veya yasak evlilik ilişkisi kapsamında cinsel ilişkiye girilmesi gibi) suç uydurma suçundan bahsedilemeyecektir. ${ }^{86}$

Gerçekten işlenmiş bir suçun cezasını artırmak maksadıyla delil veya emarelerine eklemeler yapılması suretiyle ihbarda bulunulması durumunda

80 Yaşar, Gökcan ve Artuç (n 7) 7919.

81 Aynı yönde bkz. Hafizoğulları ve Özen (n 22) 153.

82 Önder (n 5) 274; Tezcan, Erdem ve Önok (n 8) 1383.

83 Bkz. TCK m. 281: "Gerçeğin meydana çıkmasını engellemek amacılla, bir suçun delillerini yok eden, silen, gizleyen, değiştiren veya bozan kişi, altı aydan beş yıla kadar hapis cezası ile cezalandırllır. Kendi işlediği veya işlenişine iştirak ettiği suçla ilgili olarak kişiye bu fikra hükmüne göre ceza verilmez."

84 Tezcan, Erdem ve Önok (n 8) 1384; Özbek, Doğan ve Bacaksız (n 3) 1162.

85 Önder (n 5) 274.

86 Önder (n 5) 274-275; Soyaslan (n 7) 742. 
suç uydurma suçu oluşmayacaktır. ${ }^{87}$ Fakat uydurulan delil veya emareler suçun niteliğini değiştirirse fail, gerçekleşmemiş bulunan bir suç bakımından yetkili mercileri harekete geçirdiğinden suç uydurma suçunu işlemiş olacaktır.

Kanun maddesinde geçen "soruşturma yapılmasını sağlayacak biçimde" ifadesi ${ }^{88}$, failin uydurduğu delil veya emareler ile soruşturma makamlarının bilgilenmesini sağlayacak önlemler alması ve girişimlerde bulunmasını gerektirmektedir. ${ }^{89}$ Kanun burada uydurulan delil veya emarelerin adli makamlara ulaşma şeklinin nasıl olduğunu belirtmemiştir. Hali hazırda sırf bir hareketi cezalandırdığı için ihbarı da gerekli görmemiştir. Bu duruma örnek olarak kaza izlerinin suç izleri haline getirilmesi verilebilir. ${ }^{90} \mathrm{Bu}$ durumda yetkili makamların olaya müdahale etmesi durumunda söz konusu elverişlilik şartı da sağlanmış olacaktır. ${ }^{91}$

Doktrinde Erem, delil veya emare uydurmanın tek başına suç uydurma suçuna vücut vermeyeceğini, ayrıca ihbarın da gerekli olduğunu savunmaktadır. ${ }^{92}$ Ancak bakıldı̆̆ında TCK m. 271/2 soyut bir tehlike ihtiva etmektedir. Soruşturma organlarını harekete geçirmeye ilişkin elverişli şekilde dava malzemesinin uydurulması yeterli sayılmıştır. Tipiklik bakımından kanunun aramadığı ihbar şartını, bu seçimlik hareket bakımından aramak TCK'nın suç sistematiği ile de bağdaşmamaktadır.

Doktrinde ceza soruşturmasını başlatmaya elverişli olma koşulunun, şekli uydurma açısından geçerli olmadığına yönelik bir görüş söz konusudur. ${ }^{93}$ Suçun kanundaki düzenleniş amacı ve lafzı dikkate alındığında sadece maddi suç

87 Parlar ve Hatipoğlu (n 2) 4264.

88 Kanunda yazılı bu ifade, suç uydurma suçu ile başkasına ait kimlik veya kimlik bilgilerinin kullanılması suçu arasındaki en temel farkın göstergesidir. Suç uydurma suçunda fail, işlenmediğini bildiği bir suçu, yetkili makamlara işlenmiş gibi ihbar etmekte ya da işlenmeyen bir suçun delil veya emarelerini soruşturma yapılmasını sağlayacak biçimde uydurmaktadır. Fail burada uydurulan suçun işlenmediğini bilmektedir. Başkasına ait kimlik veya kimlik bilgilerinin kullanılması suçunda ise fail, işlenmediğini bildiği bir suçu uydurmamakta, işlediği iddia olunan suçun soruşturma veya kovuşturmasını engellemek amacıyla başkasına ait kimlik bilgilerini kullanmaktadır. Kerim Çakır, "5237 Sayılı Türk Ceza Kanunu’nda Başkasına Ait Kimlik veya Kimlik Bilgilerinin Kullanılması Suçu” (2013) Marmara Üniversitesi Hukuk Fakültesi Hukuk Araştırmaları Dergisi 19 (2) (Prof. Dr. Nur Centel'e Armağan) 1547; Meran (n 17) 270.

89 Parlar ve Hatipoğlu (n 2) 4263; "Sanığın evlerinden hırsızlık yapıldı̆̆ı izlenimi yaratmak için evi dağıtıp, giriş kapısına hasar vererek soruşturma yapılmasını sağlayacak biçimde deliller uydurduğu anlaşılmasına göre sanığın atılı suçtan mahkumiyeti yerine yazılı şekilde beraat karart verilmesi, yasaya aykırı..."Y8.CD, 2019/1576E., 2020/17467K., 26.10.2020T. Önder (n 5) 275.

91 Önder (n 5) 275.

$92 \quad$ Erem (n 8) 522

93 Ünver (n 9) 202-203; Asım Kaya, "Suç Uydurma Suçu ve Savunma Hakkı İlişkisi”" (2017) Terazi Hukuk Dergisi 12 (136) 77. 
IIIIIIIII!

uydurma fiili bakımından elverişlilik koşulunun aranılabileceği savunulmuştur. Ancak bu görüş, suçun unsurları bağlamında incelendiğinde sakıncalıdır. Suç uydurma suçu, sırf davranış suçudur. Bu bağlamda suçun gerçekleşmesi için adli makamların soruşturmaya başlaması ya da yetkili makamların aldatılmış olması aranmaz. İhbarın aldatıcı nitelikte olması gerekmektedir. Suç uydurma suçu neticesiz bir suçtur; herhangi bir neticenin doğması şart değildir. Bu suçta hem kanun sistematiğinde düzenlendikleri yer açısından korudukları hukuki değer bağlamında hem de herhangi bir sonucun gerçekleşmesi aranmayıp salt uydurma suça ilişkin ihbar cezalandırıldığından elverişlilik koşulunun şekli suç uydurma suçu bakımından da aranması, suçun kanuni unsuru bağlamında değerlendirilemez. Bu durum suçun doğasından kaynaklanmaktadır. Adliyeyi yanıltacak ve boş yere mesaisini harcayacak nitelikteki fiil uydurmalarının cezalandırılması, bunların araştııılmaya elverişli olmasını gerektirmektedir.

\section{TIPIIKLİĞIN MANEVİ UNSURU}

Suç uydurma suçu yalnızca kasten işlenebilen bir suçtur. ${ }^{94} \mathrm{Bu}$ suç bağlamında failin saikinin önemi bulunmamaktadır. Kanun, suçun oluşabilmesi için failin işlenmediğini bildiği bir suçu ihbar etmesini ya da delil veya emare uydurmasını aradığ 1 için bu suçun ancak doğrudan kastla işlenebildiği görülmektedir.95 $\mathrm{Bu}$ suçun dolaylı (olast) kastla işlenebilmesi mümkün değildir.96 Nitekim ilgili maddede "işlenmediğini bildiği" ifadesine yer verilmek suretiyle açık bir biçimde doğrudan kast aranmıştır. İlgili suç tipinde olumsuz bir harekete bilerek neden olmak somut bir biçimde arandığında olası kastın varlığından söz edilemeyecektir. ${ }^{97}$ Sonuç olarak anlatılan gerekçelerle suç uydurma suçunun olas1 kastla işlenemeyeceği kanaatindeyiz..$^{98}$ İlaveten belirtmek gerekir ki kanunda suçun taksirli hali öngörülmediği için failin taksirle hareket etmiş olması halinde cezalandırılabilmesi mümkün değildir.

Kişinin kendisini kurtarma amacıyla işlenmediğini bildiği bir fiili ihbar etmesi ya da işlenmeyen bir suçun delil veya emarelerinin uydurulması kişiyi cezai sorumluluktan kurtarmayacaktır. Örnek vermek gerekirse kasten öldürdüğ ü kişi ile beraber başkaları tarafından saldırıya uğradığı, cebir ve

94 Parlar ve Hatipoğlu (n 2) 4264.

95 Failin, gerçekleşmesini kendi davranışının sonucu olarak öngördüğü sonuç doğrudan kast kapsamındadır (Artuk, Gökcen, Alşahin ve Çakır (n 24) 397). Fail bu sonuç haricinde, gerçekleşme riskini kabul ettiği ya da davranışı gerçekleştirirken önlemeyi düşünmediği fakat gerçekleşmesi muhtemel sonuçlardan sorumluluğu ise olası kast (dolaylı kast) olarak karşımıza çıkmaktadır (Erdal Yerdelen, Cezanın Belirlenmesi (Türk ve Alman Uygulaması) (1. Bask1, Adalet Yayınevi 2013) 225).

96 Özbek, Doğan ve Bacaksız (n 3) 1163; Aksi yönde bkz. Kaya (n 93) 74.

97 Heinrich (n 44) 179.

98 Aynı yönde bkz. Tezcan, Erdem ve Önok (n 8) 1384; Aksi yönde bkz. Serttaş (n 34) 29 ve Yaşar, Gökcan ve Artuç (n 7) 7922. 
tehditle paralarının yağmalandığını ve bu suretle bu kişinin öldürüldüğünü, kendi fiilini örtbas etmek amaciyla ihbar eden fail sadece insan öldürme suçundan değil aynı zamanda suç uydurma suçundan da cezalandırılacaktır.99 Ayrıca belirtmek gerekir ki kişinin gerçekte işlemediği bir suçun faili olduğunu yetkili makamlara ihbar etmesi de suç uydurma suçunu oluşturmayacaktır. Failin bu fiili, diğer şartları da mevcutsa suç üstlenme suçu (TCK m. 270) teşkil edebilecektir. ${ }^{100}$ Nitekim suç üstlenme suçunda fail, işlemediği suçla kendi kendini itham etmekte iken suç uydurma suçunda, gerçekte işlenmemiş suçun faili olarak kimse gösterilmemektedir. ${ }^{101}$ Suç üstlenme suçunda fail, gerçekte hiç işlenmemiş veya başkası tarafindan işlenmiş olan bir suçu kendisinin işlediğinden bahisle yetkili makamlara bildirimde bulunmaktadır.

Suç uydurma suçunun işlenmesinde kanun herhangi bir saik aramamıştır. Bu suçlarda adliyenin kandırılması şart değildir. Şaka, alay ve benzeri saiklerle bu suçun işlenmesi de ayrıca kastı kaldırmayacaktır. ${ }^{102}$

Failin işlendiği hususunda şüpheye düştüğü durumlarda ihbarda bulunması fiili, kastı bulunmadığı gerekçesiyle suç oluşturmayacaktır. ${ }^{103}$ Ayrıca failin gerçekleşmediğini tasavvur ederek ihbarda bulunduğu suç tesadüfen işlenmişse, suç uydurma suçunun gerçekleştiğinden bahsedilemeyecektir. Nitekim kanun suç uydurma suçunun oluşması için işlenmeyen bir suçun ihbar edilmesini aramaktadır. Burada fail TCK m. 30/1 hükmü gereği tipikliğin maddi unsurlarında hataya düşmektedir. Bu hatası sebebiyle fail kasten hareket etmiş sayılmayacaktır. ${ }^{104}$ Aynı durum maddi uydurma fiili için de geçerlidir. Failin gerçekte delil veya emare olarak tasavvur ettiği bir eşyanın aslında delil veya

99 Başka bir örnek vermek gerekirse parasının çalındığı görüntüsü yaratacak şekilde delil veya emare uyduran hileli iflas suçunu işleyen failin de her iki suçtan cezalandırılması gerekmektedir. Erem ve Toroslu (n 8) 209.

100 Yokuş Sevük (n 8) 662.

101 Y16.CD, 2020/5779E., 2020/4892K., 24.9.2020T.

102 Erem ve Toroslu (n 8) 210; Artuk, Gökcen ve Yenidünya (n 63) 1158.

103 İftira suçuyla ilgili olarak suç uydurma suçu bakımından da önem arz eden Yargıtay kararları için bkz. "Sanığın paralarını koyduğu yerde bulamayınca, evinin anahtarını verdiği, çiftliğinde çalışan yakınanların alabileceği şüphesiyle ilgili gerçek bir olayın soruşturulması amacıyla yakınmada, iftira suçunun hukuka aykırılık öğesinin ne suretle oluştuğu tartışılmadan ve yakınanların suçsuz olduğunu bilerek suç yüklediğine ilişkin kanttlar gösterilip açılkanmadan hükümlülügüne karar verilmesi... ”Y4.CD, 2002/11353E., 2002/14251K., 7.10.2002T;

"Oluşa ve dosya içeriğine göre, geceleyin evinden bazı eşyalarının alınmıs olduğunu ve o gün devaml olarak kendisini ve evini sorduğu için alacaklısı Mehmet'den şüphelendiğini bildiren sanığın, bu savunmasının aksini kanıtlayan kesin ve inandırıcı hiçbir delil elde edilmediği anlaşıldığından; yasal şikayet hakkını kullanmış sayılacağı, bu nedenle müsnet suçun unsurlarının teşekkül etmediği gözetilmeden mahkumiyetine karar verilmesi,... bozmayı gerektirmiştir.” Y4.CD., 1985/8571E., 1985/120K., 22.1.1985T. Yıldırım (n 3) 123.

104 Tezcan, Erdem ve Önok (n 8) 1384. 
IIIIIIIIII!

emare niteliğini haiz olmaması durumunda ya da işlendiğini uydurduğu suçun suç vasfını haiz olmaması durumunda hata hükümleri uygulanabilecektir. ${ }^{105}$

\section{HUKUKA AYKIRILIK UNSURU}

Doktrinde bir görüşe göre faili bilinmeyen gerçekleşmiş bir suçun ihbar veya şikayet edilmesi eğer hakkın kullanımı niteliğindeyse ya da görevin ifası bakımından kişiler için bir yükümlülük teşkil ediyorsa, suç ihbarında bulunulması hukuka uygun olacak ve suç uydurma suçu oluşmayacaktır.106 $\mathrm{Bu}$ bağlamda değerlendirmede bulunulabilmesi için hukuka uygunluk sebebi teşkil edebilme kapasitesine sahip durumların incelenmesi gerekecektir.

\section{Hakkın Kullanılması}

Anayasamızın 74. maddesine göre: "Vatandaşlar ve karşıllılılık esası gözetilmek kaydryla Türkiye'de ikamet eden yabancular kendileriyle veya kamu ile ilgili dilek ve şikayetleri hakkında, yetkili makamlara ve Türkiye Büyük Millet Meclisine yazı ile başvurma hakkına sahiptir." Doktrinde bir görüşe göre dilekçe hakkının kullanımı niteliğinde olan ve işlenmediği bilinmeyen bir suçun uydurulması, TCK m. 26/1 bağlamında suç oluşturmayacaktır. ${ }^{107}$ Ancak burada işlenmediği bilinmeyen bir suçun uydurulmasında hukuka uygunluk sebebi değil kast araştırılması yapılmalıdır. Burada kişinin suç uydurmaya yönelik kastı olmadığı için suç uydurma fiili hukuka uygun olarak değerlendirilemeyecektir. Burada tipikliğin manevi unsurunun (kast) söz konusu olmadığı sonucuna ulaşılmalıdır.

Hakkın kullanılması hukuka uygunluk sebebi bağlamında değerlendirilmesi gereken hususlardan birisi de savunma hakkının kullanılmasıdır. ${ }^{108}$ Kişiler üzerine atılı suçlarla ilgili savunmalarını gerçekleştirirken, kendilerini atılı suçtan soyutlamak amacıyla suç uydurabilirler. Bu bağlamda kişinin suçsuzluğunu ispat etmek ya da suçluluğunu bastırmak amacıyla suç uydurması, savunma hakkının kullanılması bağlamında hukuka uygunluk sebebi teşkil edebilecektir. Nitekim Yargıtay bir kararında bu hususu şu şekilde açıklığa kavuşturmuştur: "Suç uydurma suçunun oluşabilmesi için, kişinin işlenmediğini bildiği bir suçu, yetkili makamlara işlenmiş gibi ihbar etmesi ya da işlenmeyen bir suçun delil veya

105 Maddi uydurmada aksi görüşle ilgili tartışma için bkz. Toroslu (n 10) 333.

106 Parlar ve Hatipoğlu (n 2) 4264; Bu suçta hiçbir hukuka uygunluk sebebinin söz konusu olmadığı görüşü için bkz. Hafizoğulları ve Özen (n 22) 155.

107 Malkoç (n 72) 4656; "Mahkemece, kanıtlar değerlendirilip gerektirici nedenleri açıklanmak suretiyle fiilin anayasal şikayet hakkı kapsamında kaldlğ gerekçesiyle verilen beraat kararı usul ve yasaya uygun bulunduğundan..." Y8.CD, 2019/13247E., 2020/16403K., 1.10.2020T.

108 Adli mekanizmayı koruyan suç kalıpları bakımından savunma hakkı genel bir hukuka uygunluk nedeni olarak değerlendirilir. Hamide Zafer, "Savunma Hakkı ve Sınırları" (2013) Marmara Üniversitesi Hukuk Fakültesi Hukuk Araştırmaları Dergisi 19 (2) 526 
emarelerini soruşturma yapılmasını sağlayacak biçimde uydurması gerektiği; sanı̆̆ın hakkında hükmedilen tedbir kararına istinaden yükümlülüklerini yerine getirmesi amactyla gönderilen tebligatlar üzerindeki imzaların isim belirtilmeksizin kendisine ait olmadı̆̆ına dair beyanı üzerine PTT tebligat görevlisi ... hakkında resmi belgede sahtecilik suçundan soruşturma başlatılan ancak bilahere söz konusu imzaların kendisine ait olduğunu kabul etmesi ile mağdur hakkında takipsizlik kararı verilen olayda eyleminin kendisini suçtan kurtarmaya yönelik savunma hakkı kapsamında değerlendirilmesi gerektiği ve atılı suçun yasal unsurları itibariyle oluşmadiğg gözetilmeden beraati yerine yazıl şekilde mahkumiyetine karar verilmesi, kanuna aykirl..."

Savunma hakkı bağlamından suç uydurma fiilinin hukuka uygunluk sebebi teşkil edebilmesi için bu hakkın nemo tenetur ilkesi bağlamında kullanılıyor olması gerekmektedir. Kişinin kendisini, üzerine atılı suçtan soyutlaması amacıyla suç uydurması hukuka uygun kabul edilmelidir."10 Ancak yine de hakkın kötüye kullanılması söz konusu ise bu durum hukuka uygunluğu bertaraf edecektir."11 Yargıtay bir kararında"12; bir kişinin kendisini kaza ile yaraladığı bir olayda, cezalandırılacağı endişesiyle tanımadığı başka kimselerce yaralandığını iddia etmesini savunma dokunulmazlığı kapsamında değerlendirmiştir. ${ }^{113}$ Doktrinde Yargıtay'ın gerçekte mevcut olmayan bir suça ilişkin savunma kapsamında suç uydurma fiillerinin hukuka uygunluk sebebi teşkil edeceği kabulü haklı olarak eleştirilmektedir. ${ }^{114} \mathrm{Bu}$ görüşe göre sanık yalan beyanda bulunsaydi; ancak suç teşkil eden bir fiil uydurmasaydı bu durum savunma hakkı ve nemo tenetur ilkesi bağlamında mütalaa edilebilirdi. Kanaatimizce sanı̆̆ın daha basit yoldan geçmeyi tercih etmeyip de suç uydurması hayatın olağan akışına aykırıdır. Bu kapsamda da sanığın eylemi meşru sınırları aştığı için suç uydurmadan dolayı sorumlu tutulması gerekir. Ancak içinde bulunduğu durum göz önüne alındığında TCK m. 61 uyarınca cezasının alt sınıra yaklaşarak belirlenmesi yoluna gidilebilecektir.

\section{Görevin İfası}

İhbarda bulunmaya yönelik bildirim yükümlülüğü, kural olarak TCK bağlamında bir yükümlülük değildir. Ancak istisnai olarak örneğin bilgi

109 Y16.CD, 2015/7780E., 2016/1775K., 17.3.2016T.; Ayn1 yönde bkz. Y14.CD, 2011/15E., 2011/39K., 13.7.2011T. Kaya (n 93) 78.

110 Özbek, Doğan ve Bacaksız (n 3) 1163.

111 Özbek, Doğan ve Bacaksız (n 3) 1163.

112 Y8.CD, 2012/8835E., 2013/13404K., 26.4.2013T. Ünver (n 9) 190.

113 Kişinin kendisini bağlayıp etrafa bir saldırganla boğuştuğu izlenimi vererek yağma suçunun mağduru olduğunun ihbar edilmesi örneği için bkz. Sönmez (n 34) 68.

114 Bkz. Ünver (n 9) 190; Suç uydurma ve iftira suçunun savunma dokunulmazlığına ilişkin TCK m. 128 kapsamında değerlendirilemeyeceği görüşü için bkz. Tezcan, Erdem ve Önok (n 8) 673. 
IIIIIIIIII-

vermeme suçunda (TCK m. 166) ${ }^{115}$, kamu görevlisinin suçu bildirmemesi suçunda (TCK m. 278) ihbarda bulunmak bir yükümlülük olarak düzenlenmiştir. Kanunun kişilere ihbar yükümlülüğü yüklemediği durumlarda görevin ifası kapsamında suç uydurma fiilleri hukuka uygun sayılamayacaktır. Bildirim yükümlülüğünün öngörüldüğü istisnai durumlarda görevin ifas1 bağlamında gerçekte işlendiği hususunda yanılarak suç uydurmaya yönelik bildirim fiilleri hukuka uygun sayılamayıp tipiklik hatası kapsamında TCK m. 30/1 değerlendirilebilecektir. Bu kapsamda da fail kasten hareket etmiş sayılamayacağı için faile ceza verilemeyecektir.

\section{SUÇUN ÖZEL GÖRÜNÜŞ BİÇİMLERİ}

\section{Teşebbüs}

Suç uydurma suçu sırf hareket suçu niteliğindedir. Ayrıca bir zararın doğması ve soruşturma veya kovuşturmanın açılması somut olarak aranmadiğından bu suç soyut tehlike suçu niteliğindedir. Buradan hareketle bu suç, işlenmediği bilinen suçun ihbar edilmesi veya delil veya emare uydurulması ile tamamlanmaktadır. ${ }^{116} \mathrm{Bu}$ bağlamda netice aranmadığı için bu suç neticesiz bir suçtur. Bu tarz suçlarda da kural olarak teşebbüs mümkün değildir. Hareketin parçalara bölünebildiği durumlarda ise bu suça teşebbüs mümkün olabilecektir. ${ }^{117}$ Nitekim Yargitay da bu suça teşebbüs edilebilmesini mümkün görmektedir. ${ }^{118}$ İhbarın yetkili makamlara ulaşması anına kadar geçen süre, bu hareketin dönülmesi mümkün hareket olarak değerlendirilmesini sağlamaktadır. ${ }^{119}$ Ancak burada teşebbüsten bahsedebilmek için failin suç yoluna (iter criminis) girmiş olması gerekmektedir. Örneğin failin başka bir suç soruşturması kapsamında üstü aranırken cebinde Cumhuriyet savcılığına sunulmak üzere bir ihbar dilekçesi bulunursa, bu durumda fiilin teşebbüs aşamasında kaldığı söylenemeyecektir. ${ }^{20}$ Çünkü fail suç yoluna girmemiştir. Failin suç yoluna girdiğinin kabulü için, örneğin dilekçeyi ibraz etmek üzere örneğin postalaması ama postanın ulaşamaması gerekmektedir. Burada teşebbüsü mümkün kılan kural, failin hazırlık hareketlerinden soyutlanıp suç

115 Bilgi vermeme suçu bakımından ihbar yükümlülüğünün kapsamı ile ilgili bkz. Burak Taş, "Bilgi Vermeme Suçu” (2021) Selçuk Üniversitesi Hukuk Fakültesi Dergisi 29 (2) 1314 vd.

116 Maddi uydurma bakımından uydurulan delil veya emarelerin yetkili merciin bilgisine ulaşmakla suçun tamamlandığı görüşü için bkz. Yaşar, Gökcan ve Artuç (n 7) 7921 ve Yasin Aydın, İftira Suçu (1. Bask1, Adalet Yayınevi 2019) 141.

117 Malkoç (n 72) 4656.

118 'Sanı̆̆ın, tanık Mustafa'yı müdahilin evine esrar koymak üzere teşvik ve esrarı tedarikle Mustafa'ya verirken yakalanmış olmasına göre, suç tasni eylemek suçu teşebbüs halinde kalmış iken, bazı mütalaa beyanıyla bu suçtan beraat kararı verilmesi yolsuzdur.” Y4.CD, 1949/2724E., 1949/3850K., 10.3.1949T. Y1ldirım (n 3) 142.

119 Erem (n 8) 523.

120 Erem (n 8) 523. 
yoluna girmesi; ancak elinde olmayan sebeplerle fiili tamamlayamamasıdır.

Maddi suç uydurma fiilinin ne zaman tamamlanmış sayılacağına ilişkin doktrinde iki farklı görüş söz konusudur. Bir görüş bu suçun tamamlanmış sayılabilmesi için yetkili makamların gerçeğe aykırı biçimde uydurulan delillere ulaşmasının şart olduğunu savunur. ${ }^{121}$ Katıldığımız diğer görüşe göre ise maddi suç uydurma fiilinin tamamlanmış sayılması için yetkili makamların delil veya emarelere ulaşması gerekmemekte; sadece gerçeği yansıtmayan delil veya emarelerin uydurulması yeterlidir. Bu düşünceye göre, "delillerin uydurulması bir muhakemenin başlaması ihtimalini ortaya çıkarmak açısından yeterlidir; delillere yetkili organlarca ulaşılması muhakemeyi başlatır ki, bu da suç uydurma suçunun gerçekleşmesi açısından şart değildir." ${ }_{122}$ Suçun kanuni tanımı da savunduğumuz bu görüşe cevaz vermektedir.

\section{2. İştirak}

Suç uydurma suçu özgü bir suç teşkil etmemektedir. ${ }^{123}$ Dolaylı faillik bakımından da ayrık bir durum öngörmemiştir. Bu açıdan bu suçun işlenmesinde TCK m. 37 bağlamında iştirak hükümlerinin uygulanmasında özellik arz eden bir durum bulunmamaktadır.

Suç uydurma suçunda iştirak hükümlerinin bütünü uygulanma imkânı bulabilecektir. Nitekim Yargıtay bir kararında suç uydurma suçuna yardım etme bağlamında şu şekilde karar vermiştir: "Yargılamaya konu iddianamede sanığın eyleminin "suç uydurma suçuna yardım olarak" anlatılması ve sevk maddesinin de bu şekilde düzenlenmesine karşın 5271 sayılı CMK'nın 226. maddesine aykırı bir şekilde sanığa ek savunma hakkı tanınmadan TCK 271/1. maddesi gereğince yazılı şekilde hüküm kurularak savunma hakkının kısıtlanması, bozmayı gerektirmis....”. ${ }^{124}$

\section{3. İçtima}

Failin yetkili makamlara birden fazla farklı suç uydurarak ihbarda bulunması veya suç işleme kararı kapsamında değişik zamanlarda birden fazla suç uydurması durumunda zincirleme suç hükümleri (TCK m. 43) uygulanabilecektir. ${ }^{25}$ Nitekim ilgili maddenin son cümlesinde mağduru belli bir kişi olmayan suçlarda da zincirleme suç hükümleri uygulanacağ 1 belirtilmiştir. Fail aynı suç işleme kararı kapsamında suçu takibe yetkili makamları harekete geçirecek şekilde birden çok kez suç uydurmuşsa, zincirleme suç hükümlerinin uygulanacak ve faile verilecek ceza dörtte

121 Söz konusu görüşlerden biri Toroslu'nun aktarmasına göre Guadagno’ya aittir. Bkz. Guadagno (n 11) 62, 63 (Aktaran Toroslu (n 10) 334).

122 Toroslu (n 10) 334.

123 Kaya (n 93) 75.

124 Y16.CD, 2015/7280E., 2016/3175K., 22.4.2016T. Kaya (n 93) 75.

125 Kaya (n 93) 75. 
IIIIIIIIIII

birinden dörtte üçüne kadar artırılacak (TCK m. 43/1) ve işlenen suç sayısı göz önünde bulundurularak üst sınıra yaklaşılacaktır (TCK m. 61). Failin tek bir ihbar mektubu ile birden fazla suç uydurması durumunda doktrinde bir görüşe göre her bir suçun işlenip işlenmediği ayrıca soruşturulacağından ${ }^{126}$ TCK m. 43/1 bakımından "değişik zamanlarda" kıstası sağlanacağından zincirleme suç hükümleri uygulanabilecektir. Ancak burada tek bir ihbar mektubu ile birden fazla suç uydurulması "değişik zamanlarda" kıstasını sağlamadığ için TCK m. 43/1 hükmü uygulanamayacaktır. ${ }^{127}$

Failin başka bir suçun işlenmesi veya işlenmiş olan bir suçun gizlenmesi amacıyla suç uydurması durumunda gerçek içtima kuralı gereği cezalandırılması gerekmektedir. Örnek vermek gerekirse yetkili makamlara kendisine teslim edilen bir eşyanın çalındığını bildiren ve onu mal edinen fail hem suç uydurma hem de güveni kötüye kullanma suçlarından cezalandırılacaktır. ${ }^{28}$

Failin gerçek dışı ihbarında belirli bir kişiyi hedef göstermeyip de kovuşturma evresinde uydurduğu suçun belirli bir kişi tarafindan işlendiğini belirtmesi durumunda gerçek içtima kuralı gereği failin sonradan eklenen kastı göz önünde bulundurularak hem iftira hem de suç uydurma suçundan ayrı ayrı cezalandırılması gerekecektir. ${ }^{129}$ Doktrinde diğer bir görüsse göre bu ihtimalde tali norm niteliğinde olan suç uydurma, asli norm niteliğinde olan iftira suçunun gerisine çekilir ve fail sadece iftira suçundan dolayı cezalandırılmalıdır. ${ }^{130}$ Eğer fail hareketlerinin başında bu durumu öngörmeyip daha sonra kastını değiştirerek suç yolunda ilerlemişse eklenen kast sebebiyle suç uydurmanın iftira suçuna evrildiği kabul edilmeli ve fail gerçek içtima kurallarına göre cezalandırılmalıdır. ${ }^{131}$ Başka bir görüşe göre ise failin kastında gerçekleșen değişimin çok kısa bir zaman diliminde vuku bulması halinde tek bir hareket olduğu kabul edilmeli ve fail yalnızca sonraki kastına ilişkin olarak iftira suçundan sorumlu tutulmalıdır. Eğer ihbar soruşturmanın değişik safhalarında gerçeklemişse burada hareket birliğinden söz etmek mümkün olmayacak ve belirli bir kişiye sonraki suç isnadında iftira ve suç uydurma ayrı ayrı gündeme gelecektir. ${ }^{132}$ Ancak diğer bir görüşe göre suç uydurma suçunun yapısı incelendiğinde bu suç sırf hareket suçudur ve işlenmeyen suçun ihbar edilmesi ya da delil veya emarelerinin uydurulmasıyla bu suç tamamlanmaktadır. $\mathrm{Bu}$ bağlamda ihbardan sonraki zaman diliminde, failin uydurduğu suçun başka birine isnad edilmesi; yani belirli bir kişinin hedef gösterilmesi halinde failin hem suç uydurma hem de iftira suçlarından ayrı ayrı cezalandırılması yoluna

\footnotetext{
126 Yaşar, Gökcan ve Artuç (n 7) 7923.

127 Aynı yönde bkz. Hafizoğulları ve Özen (n 22) 154.

128 Erem ve Toroslu (n 8) 207; Parlar ve Hatipoğlu (n 2) 4265; Erem (n 8) 523.

129 Aydın (n 116) 141; Özbek, Doğan ve Bacaksız (n 3) 1163.

130 Tezcan, Erdem ve Önok (n 8) 1384; Bayraktar (n 62) 205.

131 Bayraktar (n 62) 205; Yaşar, Gökcan ve Artuç (n 7) 7924.

132 Özbek, Doğan ve Bacaksız (n 3) 1163.
} 
gidilmelidir. ${ }^{133}$ Kanaatimizce iftira suçu ile suç uydurma fiilleri aras1 geçiş, isnad bağlamında gerçekleşmektedir ve uydurulan suçun belirli bir kişiye isnadında iftira bakımından suç uydurma fiilinden geçilmektedir. Bu bağlamda kısa zaman aralığında uydurulan suçun belirli bir kişiye isnadında geçitli suç hükümleri gündeme gelecek ve sadece iftiradan dolayı sorumluluk söz konusu olacaktır.

Başka bir ihtimal olarak zimmet fiilini işleyen kamu görevlisinin fiili, zimmetin açığa çıkmamasını sağlamaya yönelik hileli davranışlarla işılenmesi hali de incelenmelidir. Doktrinde bir görüşe göre bu ihtimalde bileşik suçun varlığı gündeme gelecektir. ${ }^{134}$ Burada hileli davranış olarak işlenmediği bilinen başka bir suçun uydurularak adli makamların kandırılması söz konusudur. Hileli hareket teşkil eden suç uydurma fiili zimmet suçunun nitelikli halini oluşturmaktadır. ${ }^{135} \mathrm{Bu}$ nedenle sadece zimmet suçunun cezası yarı oranında artırılacaktır, ayrıca suç uydurma suçundan ceza verilemeyecektir (TCK m. 247/2). ${ }^{136}$ Benzer bir örnek hileli iflas suçu için verilebilir. Hileli iflas suçunu işlemek için paralarının çalındığını izlenimini yaratacak şekilde delil veya emareler uyduran kişi, sadece hileli iflas suçundan cezalandırılmalıdır. Çünkü burada suç uydurma, hileli iflas suçunun unsuru olan hileyi teșkil etmektedir. ${ }^{137}$ Ancak bileşik suçun düzenlendiği TCK m. 42 incelendiğinde "tek fiil sayılan" ibaresi, unsur ya da ağırlatıcı sebep olan suçun söz konusu suçta açıkça belirtilmiş olmasını gerektirmektedir. ${ }^{138}$ Kanaatimizce kanunda açıça suç uydurma suçu zimmetin ve hileli iflas suçunun bir unsuru yahut ağırlaştırıcı nedeni sayılmadığı için burada bileşik suç ilişkisinden bahsedilemez. Burada suç uydurma fiili hilenin ayrılmaz bir parçası olduğundan suç uydurma fiilinin unsur olma özelliği kanunda gösterilmediği için suç uydurma suçu, geçitli suç olarak zimmet ve hileli iflas suçlarının içinde erimektedir. Burada suç uydurma fiili hilenin gerçekleşmesi için gerekli bir basamak teşkil edeceği için ayrı bir cezaya konu olmayacaktır.

Bir Yargıtay kararında "sanığın önceden sigorta yaptırdı̆̆ deposunda hırsizlık meydana gelmediği halde sigorta bedelini almak amacıyla hırsızlı gerçekleşmiş gibi, kilidi kırıp içerideki eşyaları dağıttıktan sonra zabıtaya şikayette bulunmasindan ibaret olayda, henüz sigorta şirketine başvuru olmadığından fïl dolandırıcılık suçunu oluşturmamakta ise de; suç uydurma

133 Toroslu (n 10) 336; Aydın (n 116) 141.

134 Hafizoğulları ve Özen (n 22) 154; Toroslu (n 10) 336; Bu ihtimalde hem zimmet hem de suç uydurmadan dolayı gerçek içtima kurallarının uygulanması gerektiğini savunan görüş için bkz. Tezcan, Erdem ve Önok (n 8) 1385.

135 Tezcan, Erdem ve Önok (n 8) 1385.

136 Failin hem nitelikli zimmet hem de suç uydurmadan dolayı cezalandırılması gerektiği görüşü için bkz. Tezcan, Erdem ve Önok (n 8) 1385.

137 Erem (n 8) 523.

138 Özbek, Doğan ve Bacaksız (n 23) 332; Zafer (n 45) 574. 
IIIIIIIIII

suçunu oluşturduğu" belirtilmiştir. ${ }^{139}$ Eğer fail sigorta bedelini talep etseydi hem dolandırıcılık suçundan hem de suç uydurma suçundan sorumlu olacaktı. Bu bağlamda dolandırıcılık suçu ile suç uydurma suçu gerçek içtima kurallarına göre cezalandırılacaktı. ${ }^{10}$

Tanık sıfatıyla dinlenen kişinin, işlenmediğini bildiği bir suçu, beyanda bulunurken bildirmesi durumunda da suç uydurma suçu gündeme gelebilir. ${ }^{141}$ Nitekim bu şekilde yapılan ihbarlar üzerine yetkili makamlar harekete geçmek zorundadır. Yalan tanıklık suçunun düzenlendiği TCK m. 272 hükmü incelendiğinde "gerçeğe aykırı olarak tanıklı yapan kimse" ifadesinin içerisinde suç uydurma fiilinin de bulunması ihtimal dahilindedir. Kanaatimizce iki suç arasında fikri içtima ilişkisi (TCK m. 44) söz konusudur. ${ }^{142}$ Burada tanık sıfatına sahip olan failin, yetkili kişi veya kurul önünde ihbar niteliğinde uydurma bir suçla ilgili doğru olmayan beyanlarda bulunması hali tek bir fiil olarak değerlendirilmeli ve bu kapsamda farklı neviden fikri içtima hükümleri uygulanmalıdır.

Bir yargılamada katılanın ifadeleri suç uydurma niteliğinde ise hangi fiilden dolayı cezalandırılması gerektiğinin de açıklanması gerekmektedir. Akraba ilişkisi kapsamında tanıklıktan çekilmeyen katılan tanık sıfatına sahip olmayıp müdahil olarak değerlendirileceği için doğru olmayan ve suç uydurma niteliğindeki açıklamaları tanık beyanı olarak değerlendirilemeyecek ve yalan tanıklık suçundan sorumlu tutulamayacaktır. ${ }^{143} \mathrm{Bu}$ ihtimalde katılan sadece suç uydurma suçundan sorumlu tutulabilecektir. ${ }^{144}$

İçtima konusunda özel belgede sahtecilik ile suç uydurma arası ilişkiden de bahsetmek gerekmektedir. Şekli uydurma fiili bakımından uydurulan suça ilişkin ihbar yazılı olarak yapıldığında, özel belgede fikri sahtecilik suçunun (TCK m. 207) gündeme gelip gelmeyeceği araştırılmalıdır. Özel belgede fikri sahteciliğin mümkün olabilmesi için esasında mevcut olmadığ 1 halde mevcutmuş̧̧asına sahte bir belge üretilmelidir. ${ }^{145}$ Sahte özel bir belge düzenlenmesi "belgenin kimliğini yanlış yansıtmak" ya da "var olan gerçek

139 Y11.CD, 2003/7917E., 2004/5220K., 14.6.2004T. Ünver (n 9) 189.

140 Asım Kaya, "Sigorta Dolandırıcılığına Konu Olabilen Sigorta Türlerinin Sigorta Hukuku ve Ceza Hukuku Bakımından Sonuçları” (2015) Terazi Hukuk Dergisi 10 (101) 51, 52.

141 Yildirım (n 3) 117.

142 Aynı yönde bkz. Zafer İçer, "Yalan Tanıklık Suçu" (2018) Marmara Üniversitesi Hukuk Fakültesi Hukuk Araştırmaları Dergisi 18 (1) 224.

143 Fatih Selami Mahmutoğlu, "Ceza Yargılamasında Katılanın, Aynı Zamanda CMK 45. Maddede Öngörülen Kişilerden Biri Olması Halinde, Tanıklıktan Çekilme Hakkını Kullanıp Kullanamayacağı Sorunu” (2013) Marmara Üniversitesi Hukuk Fakültesi Hukuk Araştırmaları Dergisi 19 (2) 208.

144 Mahmutoğlu (n 143) 208.

145 Ali Parlar ve Muzaffer Hatipoğlu, Türk Ceza Kanunu Yorumu 3. Cilt (3. Bask1, Seçkin Yayıncılık 2010) 3293; Sedat Bakıcı, 5237 sayılı Yasa Kapsamında Ceza Hukuku Özel Hükümleri Cilt 2, (1. Bask1, Adalet Yayınevi 2008) 1066. 
bir belgenin taklidi" biçiminde olabilir. ${ }^{146}$ Eğer suç uyduran kimse ihbarı bir başkası adına yapmışsa ve onun adına ihbara ilişkin belgeyi imzalamışsa, o zaman hem suç uydurma hem de özel belgede sahtecilikten cezalandırılması gündeme gelebilecektir. ${ }^{147}$

Resmi belgede sahtecilik suçu bakımından (TCK m. 204) değerlendirme yapmak gerekirse göreviyle ilgili bir hususta gerçekte işlenmeyen bir suçun işlendiğine dair yazılı ihbar belgesi düzenleyen kamu görevlisi, hem suç uydurma suçundan hem de resmi belgede sahtecilik suçundan sorumlu olacaktır. ${ }^{148}$ Sahte ihbar belgesini düzenleyen kamu görevlisi ile bu belgeyi imzalayan kişi aynıysa resmi belgede fikri sahtecilik, farklı kişiler ise resmi belgede maddi sahtecilik suçundan ayrı ayrı ceza verilmelidir. ${ }^{199}$

Uygulamada failin bir başkası korumak maksadıyla suç uydurma fiilini gerçekleştirmesine oldukça sık rastlanmaktadır. Örneğin bir annenin, oğlunun işlediği insan öldürme fiili bağlamında ifadesinin alınması sırasında kolluğa olayı gördügünü; ancak öldürüldüğü iddia edilen kişinin aslında öldürülmediği, karanlıkta göremediği kişilerce kaçırıldığını söylemesi durumunda ilk bakışta suç uydurduğu görülmektedir. Ancak fail aynı zamanda suçluyu kaçırma suçunu da işlediği düşünülebilir. TCK m. 283 'te düzenlenen bu suç; "suç işleyen bir kişiye araştırma, yakalanma, tutuklanma veya hükmün infazından kurtulması için imkân sağlamak" şeklinde işlenebilir. Suçluyu kayırma suçuyla suç işleyen kişilerin ceza adaletinden kurtulmasına imkân sağlamaya yönelik fiiller cezalandırılmaktadır. ${ }^{150} \mathrm{Bu}$ açıdan annenin oğlunun işlediği fiilin soruşturulması bağlamında araştırmayı saptırmak amacıyla suç uydurması durumunda hem suç uydurmadan hem de suçluyu kayırma suçundan sorumlu tutulması gerekecektir. Her ne kadar nemo tenetur ilkesi gereği kişi kendi yakınını suçlamaya zorlanamasa da adliyeyi de meşgul etme hakkına sahip değildir. Nitekim hukuk düzeni hakkın kötüye kullanılmasını korumayacaktır. Ayrıca salt yakınlık ilişkisi bağlamında kişilerin suçluyu kayırma ve suç uydurma gibi adliyeye karşı suçlardan sorumlu olmayacağı kabulü eşyanın doğasına aykırı bir sonuç doğuracaktır.

\section{MUHAKEMESİ}

Suç uydurma suçunun cezası üç yıla kadar hapis cezası olarak öngörülmüştür. Alt sınır münferiden belirlenmediği için TCK m. 49/1 gereği alt sınır bir

146 Parlar ve Hatipoğlu (n 145) 3293.

147 Tezcan, Erdem ve Önok (n 8) 1385; Toroslu (n 10) 335.

148 Benzer yönde bkz. Yokuş Sevük (n 8) 668.

149 Toroslu (n 10) 335.

150 V. Sonay Evik, "Suçluyu Kayırma Suçu" (2010) Galatasaray Üniversitesi Hukuk Fakültesi Dergisi 9 (1) (Köksal Bayraktar'a Armağan) 724; Parlar ve Hatipoğlu (n 2) 4343; Zahit Yılmaz, "Suçluyu Kayırma Suçu (TCK m. 283)" (2012) Marmara Üniversitesi Hukuk Fakültesi Hukuk Araştırmaları Dergisi 18 (1) 153. 
IIIIIIIIIII

aydır. Hükmolunan sonuç ceza iki yıl veya daha az süreli hapis cezası ise, ceza ertelenebilecektir (TCK m. 51/1). ${ }^{151}$ Aynı şekilde şartlar gerçekleştiği nispette ceza, iki yıl veya daha az süreli hapis cezası ise mahkemece, hükmün açıklanmasının geri bırakılmasına karar verilebilir (CMK m. 231/5).

Ceza muhakemesi hukukunda aslolan suçların re'sen soruşturulması ve kovuşturulmasıdır. Şikâyet hususunda kanun koyucu sessiz kaldığı için suç uydurma suçunun soruşturulması ve kovuşturulması şikayete tabi değildir. Cumhuriyet savcısı, bu suçun işlendiği izlenimini veren bir hâli öğrenir öğrenmez kamu davasını açmaya yer olup olmadığına karar vermek üzere hemen işin gerçeğini araştırmaya başlayacaktır (CMK m. 160). Bu suçun uzlaştırma kapsamındaki suçlardan sayılmaması ve şikâyete tabi olmaması sebebiyle bu suç bakımından uzlaştırma hükümleri uygulanamayacaktır. Suç uydurma suçunun üst sınırı altı ay hapis cezasının üstünde olduğu için (TCK m. 75) bu suç ön ödemeye de tabi değildir. ${ }^{152}$

5235 sayılı Adlî Yargı İlk Derece Mahkemeleri ile Bölge Adliye Mahkemelerinin Kuruluş, Görev ve Yetkileri Hakkında Kanun'un 11. maddesi uyarınca bu suçla madde itibariyle yetkili mahkeme asliye ceza mahkemesidir. Yer itibariyle yetkili mahkeme ise CMK m. 12/1 gereği ihbarın yapıldığı ya da delil veya emarelerin uydurulduğu yer mahkemesidir.

TCK m. 66/1-e uyarınca bu suçta öngörülen dava zamanaşımı süresi sekiz yıldır. Dava zamanaşımını kesen sebepler söz konusu olduğu taktirde zamanaşımı süresi yeniden işlemeye başlayacaktır (TCK m. 67/3). Uzayan yeni zamanaşımı süresi bakımından TCK m. 67/4 uygulanacaktır. Söz konusu hükme göre dava zamanaşımının kesilmesi ${ }^{153}$ halinde, zamanaşımı süresi ilgili suça ilişkin olarak Kanunda belirlenen sürenin en fazla yarısına kadar uzayacaktır. Sekiz yıl olan dava zamanaşımı süresinin yarısı olan dört yıl bu

151 Ancak ertelemenin mümkün olabilmesi için failin daha önce kasıtlı bir suçtan dolayı üç aydan fazla hapis cezasına mahkûm edilmemiş olması ve suçu işledikten sonra yargılama sürecinde gösterdiği pişmanlık dolayısıyla tekrar suç işlemeyeceği konusunda mahkemede bir kanaatin oluşması gerekir (TCK m. 51/1-a,b).

152 "Sanık hakkında suç uydurma suçundan kurulan hükme yönelik sanığın temyiz isteminin incelenmesinde, TCK'nın 271/1. maddesinde düzenlenen suç uydurma fiilinin 6763 sayılı Yasanın 12. maddesi ile değişik 5237 sayıl TCK'nın 75. maddesi uyarınca ön ödeme kapsamında kalan suçlardan olmadı̆̆ anlaşılmakla, tebliğnamedeki ön ödeme ihtar yapılıp sonucuna göre sanığın hukuki durumunun değerlendirilmesi gerektiğine dair bozma görüşüne iştirak edilmemiştir. ”Y8.CD, 2020/4249E., 2020/17588K., 27.10.2020T.

153 Dava zamanaşımını kesen sebepler TCK m. 67/2'de düzenlenmiştir: Bir suçla ilgili olarak;

a) Şüpheli veya sanıklardan birinin savcı huzurunda ifadesinin alınması veya sorguya çekilmesi,

b) Şüpheli veya sanıklardan biri hakkında tutuklama kararının verilmesi,

c) Suçla ilgili olarak iddianame düzenlenmesi,

d) Sanıklardan bir kısmı hakkında da olsa, mahkûmiyet kararı verilmesi halinde, dava zamanaşımı kesilir. 
süreye eklendiğinde, dava zamanaşımının kesilmesi halinde işleyecek olan yeni zamanaşımı süresi on iki yılı geçemeyecektir. Zamanaşımı süresi dolduğunda mahkemece davanın düşmesi kararı verilecektir. ${ }^{154}$ İlaveten belirtmek gerekir ki dava zamanaşımını kesen birden fazla nedenin bulunması halinde zamanaşımı süresi, son kesme nedeninin gerçekleştiği tarihten itibaren yeniden işlemeye başlayacaktır (TCK m. 67/3). ${ }^{155}$

Basit yargılama, iddianame mahkemesince kabul edilip kovuşturma aşamasına geçildikten sonra adlî para cezasını ve/veya üst sınırı iki yıl veya daha az süreli hapis cezasını gerektiren suçlar bakımından öngörülmüş bir muhakeme türüdür. $\mathrm{Bu}$ muhakeme türünde, seri muhakeme usulünde olduğu gibi katalog suç söz konusu değildir. ${ }^{156}$ Suç uydurma suçunun üst sınırı üç y1l olarak öngörüldüğü için bu suçta basit yargılama usulü işletilemeyecektir. Seri muhakeme usulünün uygulanması noktasında kanunda belirli şartlar öngörülmüştür. ${ }^{157}$ Kanun koyucu, seri muhakeme usulünün uygulanabilmesini katalog suçlarla sınırlamıştır (CMK m. 250/1). Ayrıca basit muhakeme usulünden farklı olarak seri muhakeme usulünde takdirilik öngörülmemiştir. ${ }^{158}$ $\mathrm{Bu}$ suç, ilgili hükümde belirtilen katalog suçlardan biri olarak sayılmamıştır. Bu nedenle bu suçla ilgili seri muhakeme usulü uygulanamayacaktır.

Suç uydurma suçu, bünyesinde işlenmeyen bir suçun varlığını gerektirdiği için bu suçun muhakemesinde en az iki farklı suçun varlığ Uydurulduğu iddia edilen fiilin gerçekte var olup olmadığı hususu açıklığa kavuşturulamamışsa bu durumda failin suç uydurduğu yönündeki maddi vakıanın gerçekleştiği sonucuna varılamayacaktır. ${ }^{159}$ Nitekim uydurulduğu iddia edilen suçun işlenip işlenmediği sübuta varmamışsa bu durumda maddi

154 “Sanığın eylemine uyan 5237 sayll TCK'nın 142/1-b, 35, 116/1, 119/1-c, 271/1. maddelerinde düzenlenen hırsızlık, konut dokunulmazlığını ihlal ve suç uydurma suçları için öngörülen cezanın türü ve üst sinırına göre, aynı Kanun'un 66/1-e maddesine göre hesaplanan 8 yıllık zamanaşımının, hükmün açıklanmasının geri bırakılması nedeniyle duran 2 yıl 5 ay 7 günlük sürede dikkate alınarak ilk mahkumiyet kararının verildiği 18.12 .2008 tarihi ile ikinci mahkumiyet kararının verildiği 10.05.2019 tarihleri arasında gerçekleştiği gözetilmeden, sanık hakkındaki kamu davasının zamanaşımı nedeniyle düşürülmesi yerine yargılamaya devamla yazılı şekilde hüküm kurulması, bozmayı gerektirmiş..." Y13.CD, 2020/8791 E. , 2020/8915 K., 8.10.2020T.

155 A. Nevzat Odyakmaz ve B. Tunç Demiralp, Uygulamal1 - Örnekli Hukuk Rehberi (1. Bask1, Alfa Yayınları 2000) 15.

156 Zahit Yılmaz ve Özge Apiş, "Seri Muhakeme ve Basit Yargılama Düzenlemelerinin Değerlendirilmesi” (2020) Marmara Üniverisitesi Hukuk Fakültesi Hukuk Araştırmaları Dergisi 26 (1) 65; Ayşe Özge Atalay, "Türk Ceza Muhakemesinde Seri Muhakeme Usulü ve Mukayeseli Hukuktaki Benzer Usuller” (2020) Galatasaray Üniversitesi Hukuk Fakültesi Dergisi 19 (2) 664.

157 Atalay (n 156) 660.

158 Y1lmaz ve Apiş (n 156) 65.

159 Artuç (n 30) 1410. 
IIIIIIIIII!

vakıaya ilişkin bu şüphenin sanık yararına yorumlanması ve suç uydurma suçunun oluşmadığ sonucuna varılması gerekmektedir. ${ }^{160}$

\section{SONUÇ}

Suç uydurma suçunun koruduğu hukuki değer, kanunun sistematiğine bakıldığında en genel anlamda adliyenin işleyiş düzenidir. Doktrinde bu suçun adliyenin işleyiş düzeni, itibarı ve güvenilirliğinin yanında kişilerin adil yargılanma hakkını da koruduğu yönündeki görüşler bulunmaktadır. Ancak suç uydurma suçunda, iftira suçunda olduğu gibi hedef tutulan belirli bir kişi bulunmamaktadır. Bu suçun kamusallığı ağır bastığından ve bireysel bazda kişilerin adil yargılanma hakkı doğrudan tehlikeye sokulmadığından bu suçla doğrudan adli makamların gereksiz yere meşgul edilmemesine yönelik adli işleyişin devamlılığının korunduğu sonucuna varılmalıdır.

Söz konusu suçun seçimli hareket olarak "işlenmediği bilinen uydurma bir suçun ihbar edilmesi" yani şekli uydurma; "işlenmediği bilinen bir suçun delil veya emarelerinin soruşturma yapılmasını sağlayacak biçimde uydurulması" yani maddi uydurma şeklinde işlenebileceği görülmektedir. Burada ilk seçimlik hareket bakımından doktrinde ihbarın teknik olarak sınırlandırılmaması; izin, talep, şikayet yoluyla da bu suçun işlenebileceği savunulmuştur. Ayrıca ihbar ile sadece re'sen soruşturulan suçların değil, şikayete tabi suçların da ihbar edilmesinin suç uydurma suçuna vücut vereceği de savunulmuştur. Ancak maddi ceza normlarında, özgürlük alanını sınırlayıcı biçimde kıyasa yol açacak biçimde genişletici yorum yasağının bu görüşlere cevaz vermeyeceği açıktır.

Tipikliğin manevi unsurları bakımından incelendiğinde bu suçun yalnızca doğrudan kastla işlenebileceği görülmektedir. Doktrinde aksini savunan görüşler olsa da kanunda "işlenmediği bilinen" ifadesinin varlığ sebebiyle bu suçun olas kastla işlenmesinin mümkün olmadığ 1 sonucuna varmak gerekmektedir.

Hukuka aykırılık unsuru bakımından uygulamada bu suç için görevin ifası ve hakkın kullanılması şeklinde iki hukuka uygunluk sebebinin varlığı araştırılabilir. Hakkın kullanılması ise uygulamada en sık "savunma hakkl" kapsamında vuku bulmaktadır. Ancak savunma hakkının kullanımı da sınırsız olmamakla birlikte bu hak, nemo tenetur ilkesi bağlamında kullanıldığında hukuka uygunluk sebebi yaratacaktır. Hakkın kötüye kullanılması niteliğindeki uygulamaları hukuk düzeni korumayacaktır. Görevin ifası bakımından ise hukuka uygunluk sebebi değil TCK m. 30/1 bakımından tipiklik hatas hükümlerinin uygulanırlığı araştırılmalıdır.

Suçun özel görünüş biçimleri incelendiğinde suçun sırf hareket suçu niteliğinde olması, kural olarak teşebbüs imkanını ortadan kaldırmaktadır. Ancak hareket parçalara bölündügüü münferit durumlarda bu suça teşebbüs

160 Artuç (n 30) 1410. 
mümkün olabilecektir. İçtima bakımıdan bu suçun uygulamasında gerçek içtima, geçitli suç, zincirleme suç ve fikri içtima hükümleri önem arz etmektedir. Başka bir suçun işlenmesi veya işlenmiş olan bir suçun gizlenmesi amacıyla suç uydurması durumunda gerçek içtima kuralı işlerlik kazanacaktır. İftira suçu bakımından ise genel olarak geçitli suç hükümleri gündeme gelecektir. Yalan tanıklık suçunda ise tanıklık sıfatı bakımından farklı neviden fikri içtimadan yahut yalnızca suç uydurmadan bahsedilebilecektir.

Suç uydurma suçunun muhakemesinde en az iki farklı suçun varlığı araştırılmaktadır. Bu kapsamda da uydurulan suçun gerçekte işlenip işlenmediği ortaya konmadan suç uydurma suçu sübut bulmayacaktır. Uydurulan suçun varlığ 1 hususunda bir şüphe varsa bu şüphe sanık lehine yorumlanmalıdır.

\section{KAYNAKÇA}

Alacakaptan U, Suçun Unsurları (1. Bask1, Sevinç Matbaas1 1970).

Aldemir H, Ceza Hukuku Genel Hükümler Rehberi (1. Bask1, Adalet Yayınevi 2019).

Artuç M, Pratik Türk Ceza Kanunu (5. Bask1, Adalet Yayınevi 2019).

Artuk ME, Gökcen A ve Yenidünya C, Ceza Hukuku Özel Hükümler (15. Bask1, Adalet Yayınevi 2015).

Artuk ME, Gökcen A, Alşahin ME ve Çakır K, Ceza Hukuku Genel Hükümler (14. Bask1, Adalet Yayınevi 2020).

Artuk ME, Gökcen A, Alşahin ME ve Çakır K, Ceza Hukuku Özel Hükümler (19. Bask1, Adalet Yayınevi 2021).

Atalay AÖ, "Türk Ceza Muhakemesinde Seri Muhakeme Usulü ve Mukayeseli Hukuktaki Benzer Usuller" (2020) Galatasaray Üniversitesi Hukuk Fakültesi Dergisi, 19 (2) 653-732.

Aydın Y, İftira Suçu (1. Baskı, Adalet Yayınevi 2019).

Bakıcı S, 5237 sayılı Yasa Kapsamında Ceza Hukuku Özel Hükümleri Cilt 2 (1. Bask1, Adalet Yayınevi 2008).

Bayraktar K, "İftira” (1974) İstanbul Üniversitesi Hukuk Fakültesi Mecmuas1 40 (1-4) 181-206.

Birtek F, Ceza Hukuku Genel Hükümler Temel Bilgiler (6. Baskı, Adalet Yayınevi 2018).

Çakır K, “5237 Sayılı Türk Ceza Kanunu’nda Başkasına Ait Kimlik veya Kimlik Bilgilerinin Kullanılması Suçu” (2013) Marmara Üniversitesi Hukuk Fakültesi Hukuk Araştırmaları Dergisi 19 (2) (Prof. Dr. Nur Centel'e Armağan) 1541-1566. 
IIIIIIIIII!

Değirmenci O, "Ceza ve Ceza Muhakemesi Hukukunda Mağdur Hakları" (2008) Türkiye Barolar Birliği Dergisi 21 (77) 33-86.

Demirbaş T, Ceza Hukuku Genel Hükümler (15. Baskı, Seçkin Yayıncılık 2020).

Dündar H, "İftira Suçu ile Benzeri Suçlar üzerine Bir İnceleme" (1984) Adalet Dergisi 75 (2).

Erem F ve Toroslu N, Türk Ceza Hukuku Özel Hükümler (5. Baskı, Savaş Yayınları, 1987).

Erem F, “Suç Tasnii” (1954) Adalet Dergisi 10 (45) 1179-1185.

Erem F, Ümanist Doktrin Açısından Türk Ceza Hukuku Cilt: III (3. Bask1, Seçkin Kitabevi 1985).

Evik VS, "Suçluyu Kayırma Suçu” (2010) Galatasaray Üniversitesi Hukuk Fakültesi Dergisi 9 (1) (Köksal Bayraktar’a Armağan) 717-747.

Guadagno G, La Simulazione di Reato, Casa Editrice Dott. (Eugenio Jovene 1953).

Hafızoğulları Z ve Özen M, Türk Ceza Hukuku Özel Hükümler Millete ve Devlete Karşı Suçlar (1. Baskı, U-S-A Yayıncılık 2016).

Heinrich B, Ceza Hukuku Genel Kısım - I (Cezalandırılabilirliğin Temel Esasları - Tamamlanmış ve Teşebbüs Edilen Suçlarda Suçun Yapısı), (Ed. Yener Ünver) (1. Baskı, Adalet Yayınevi 2014).

İçer Z, "Yalan Tanıklık Suçu” (2018) Marmara Üniversitesi Hukuk Fakültesi Hukuk Araştırmaları Dergisi 18 (1) 179-226.

Kaya A, "Sigorta Dolandırıcılığına Konu Olabilen Sigorta Türlerinin Sigorta Hukuku ve Ceza Hukuku Bakımından Sonuçları" (2015) Terazi Hukuk Dergisi 10 (101) 42-52.

Kaya A, "Suç Uydurma Suçu ve Savunma Hakkı İlişkisi” (2017) Terazi Hukuk Dergisi 12 (136) 73-80.

Kazaker G, "Elverişsiz Teşebbüs ve Mefruz Suç Ayrımı" (2020) Sosyal Bilimler Araştırma Dergisi 9 (1) 129-141.

Koca M ve Üzülmez İ, Türk Ceza Hukuku Özel Hükümler (6. Bask1, Seçkin Yayınları 2019).

Kurt DH, İftira Suçu (TCK m. 267), Marmara Üniversitesi Sosyal Bilimler Enstitüsü Kamu Hukuku Anabilim Dalı Yayınlanmamış Yüksek Lisans Tezi (2020).

Mahmutoğlu FS, “Ceza Yargılamasında Katılanın, Aynı Zamanda CMK 45. 
Maddede Öngörülen Kişilerden Biri Olması Halinde, Tanıklıktan Çekilme Hakkını Kullanıp Kullanamayacağı Sorunu" (2013) Marmara Üniversitesi Hukuk Fakültesi Hukuk Araştırmaları Dergisi 19 (2) 191-210.

Malkoç I, Açıklamalı Türk Ceza Kanunu 4. Cilt (1. Baskı, Yazarın Kendi Yayını 2013).

Meran N, AİHM Kararları ile İçtihatlı-Açıklamalı Basın Yoluyla ve Genel Olarak Hakaret- İftira, Suçtan Kaynaklanan Malvarlığını Aklama, Soruşturmanın Gizliliğini İhlal Suçları (1. Baskı Seçkin Yayıncılık 2014).

Odyakmaz AN ve Demiralp BT, Uygulamalı - Örnekli Hukuk Rehberi (1. Bask1, Alfa Yayınları 2000).

Önder A, Türk Ceza Hukuku Özel Hükümler (4. Baskı, Filiz Kitabevi 1994)

Özbek VÖ, Doğan K ve Bacaksız P, Ceza Genel Hukuku (Temel Bilgiler) (15. Bask1, Seçkin Yayıncılık 2020).

Özbek VÖ, Doğan K ve Bacaksız P, Türk Ceza Hukuku Özel Hükümler (15. Bask1, Seçkin Yayıncılık 2020).

Özek Ç, “Adliyeye Karşı Suçların Hukuki Konusu”(1997) İstanbul Üniversitesi Hukuk Fakültesi Mecmuası 55 (3) (Prof. Dr. Türkan Rado'ya Armağan Sayısı) 13-50.

Pagliaro A, Principi di Diritto Penale, par. spec. (Giuffre 2000).

Parlar A ve Hatipoğlu M, Türk Ceza Kanunu Yorumu 3. Cilt (3. Bask1, Seçkin Yayınc1lık 2010)

Parlar A ve Hatipoğlu M, Türk Ceza Kanunu Yorumu 4. Cilt (3. Baskı, Seçkin Yayınc1lik, 2010)

Serttaş AT, Türk Ceza Kanunu'nda İftira Suçu (TCK m. 267), Akdeniz Üniversitesi Sosyal Bilimler Enstitüsü Kamu Hukuku Anabilim Dalı Yayınlanmamış Yüksek Lisans Tezi (2018).

Soyaslan D, Ceza Özel Hukuku (12. Bask1, Yetkin Yayınc1lık 2018)

Sönmez AS, Türk Ceza Kanunu'nda İftira Suçu (1. Baskı, Hakim Yayınları 2016).

Taş B, "Bilgi Vermeme Suçu" (2021) Selçuk Üniversitesi Hukuk Fakültesi Dergisi 29 (2) 1305-1342.

Tezcan D, Erdem MR ve Önok M, Teorik ve Pratik Ceza Özel Hukuku (18. Bask1, Seçkin Yayıncılık 2020).

Toroslu H, "Suç Uydurma Suçu" (2013) Ankara Barosu Dergisi 71 (1) 319337. 
IIIIIIIIII!

Toroslu N ve Feyzioğlu M, Ceza Muhakemesi Hukuku (19. Baskı, Savaş Yayınlar1 2019).

Ünver Y, İftira - Suç Uydurma - Suç Üstlenme - Yalan Tanıklık ve Suçu İhbar Etmemek Suçları (TCK'da Düzenlenen Adliyeye Karşı Suçlar) (6. Baskı, Seçkin Yayıncılık 2021).

Yaşar O, Gökcan HT ve Artuç M, Yorumlu-Uygulamalı Türk Ceza Kanunu Cilt IV (1. Bask1, Adalet Yayınevi 2010).

Yıldırım A, "İftira Suçu” (2007) Türkiye Barolar Birliği Dergisi 20 (69) 177-210.

Yıldırım A, İftira ve Suç Uydurma Suçları (1. Baskı, Adalet Yayınevi 2010)

Yılmaz Z ve Apiş Ö, "Seri Muhakeme ve Basit Yargılama Düzenlemelerinin Değerlendirilmesi” (2020) Marmara Üniversitesi Hukuk Fakültesi Hukuk Araştırmaları Dergisi 26 (1) 62-106.

Y1lmaz Z, "Suçluyu Kayırma Suçu (TCK m. 283)" (2012) Marmara Üniversitesi Hukuk Fakültesi Hukuk Araştırmaları Dergisi 18 (1) 147-178.

Yokuş Sevük H, Türk Ceza Hukuku Özel Hükümler (2. Baskı, Adalet Yayınevi 2019).

Yurtcan E, Yargıtay Kararları Işı̆̆ında İftira Suçu (Adliyeye Karşı Diğer Suçlar) (2. Baskı, Türkiye Barolar Birliği Yayınları: 303 2015)

Zafer H, "Savunma Hakk1 ve Sinırları" (2013) Marmara Üniversitesi Hukuk Fakültesi Hukuk Araştırmaları Dergisi 19 (2) 507-540.

Zafer H, Ceza Hukuku Genel Hükümler (TCK m.1-75) (7. Bas1, Beta Yayınc1lık 2019). 